\title{
Verpleeghuisgeneeskunde al langer officieel erkend; maar ook herkend en gekend?
}

Citation for published version (APA):

Schols, J. M. G. A. (2008). Verpleeghuisgeneeskunde al langer officieel erkend; maar ook herkend en gekend? Maastricht University. https://doi.org/10.26481/spe.20080926js

Document status and date:

Published: 26/09/2008

DOI:

10.26481/spe.20080926js

Document Version:

Publisher's PDF, also known as Version of record

\section{Please check the document version of this publication:}

- A submitted manuscript is the version of the article upon submission and before peer-review. There can be important differences between the submitted version and the official published version of record.

People interested in the research are advised to contact the author for the final version of the publication, or visit the DOI to the publisher's website.

- The final author version and the galley proof are versions of the publication after peer review.

- The final published version features the final layout of the paper including the volume, issue and page numbers.

Link to publication

\footnotetext{
General rights rights.

- You may freely distribute the URL identifying the publication in the public portal. please follow below link for the End User Agreement:

www.umlib.nl/taverne-license

Take down policy

If you believe that this document breaches copyright please contact us at:

repository@maastrichtuniversity.nl

providing details and we will investigate your claim.
}

Copyright and moral rights for the publications made accessible in the public portal are retained by the authors and/or other copyright owners and it is a condition of accessing publications that users recognise and abide by the legal requirements associated with these

- Users may download and print one copy of any publication from the public portal for the purpose of private study or research.

- You may not further distribute the material or use it for any profit-making activity or commercial gain

If the publication is distributed under the terms of Article $25 \mathrm{fa}$ of the Dutch Copyright Act, indicated by the "Taverne" license above, 


\section{Universiteit Maastricht}

Prof. Dr. Jos M.G.A. Schols

Verpleeghuisgeneeskunde al langer officieel erkend; maar ook herkend en gekend?

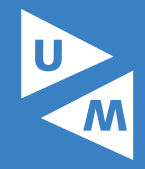

Faculty of Health, Medicine and Life Sciences
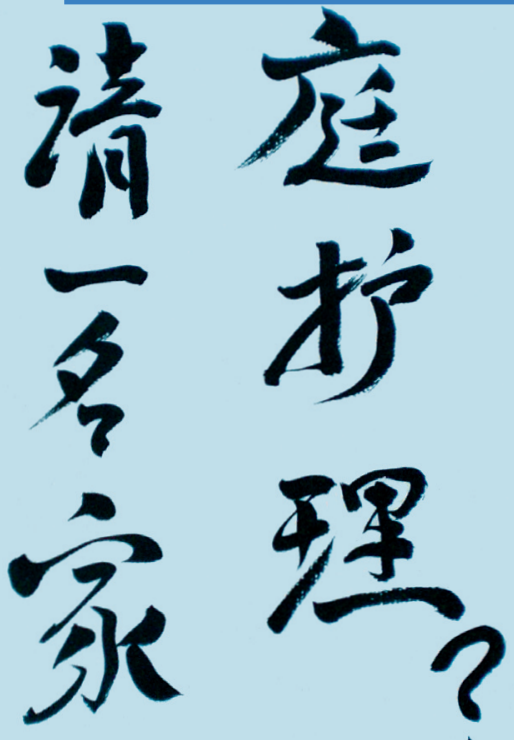

Verpleeghuisgeneeskunde al langer officieel erkend; maar ook herkend en gekend? 


\section{Colofon}

Ontwerp en print: Océ Business Services, Maastricht

Omslag: Chinese tekens op de kaft zijn de vertaling van 'nursing home medicine recognized?'

ISBN: $978-90-5681-288-1$

NUR: 870

Alle rechten voorbehouden. Niets uit deze uitgave mag worden verveelvoudigd, opgeslagen in een geautomatiseerd gegevensbestand of openbaar gemaakt worden, zonder voorafgaande schriftelijke toestemming van de auteur of uitgever. 


\section{Verpleeghuisgeneeskunde al langer officieel erkend; maar ook herkend en gekend?}

Rede

In vrije vorm uitgesproken bij de aanvaarding van het ambt van bijzonder hoogleraar Verpleeghuisgeneeskunde aan de Faculty of Health, Medicine and Life Sciences van de Universiteit Maastricht

op vrijdag 26 september 2008

door

prof. dr. Jos M.G.A. Schols

Maastricht University 
Mijnheer de Rector, waarde collega's in de breedste zin van het woord, lieve vrienden en familieleden en overige gewaardeerde toehoorders,

Vandaag wilt $U$ ongetwijfeld horen waarvoor ik beroepsmatig en ook academisch sta.

Welnu, ik sta voor de verpleeghuisgeneeskunde, een bijzonder vakgebied, voor een evenzo bijzondere doelgroep, namelijk de erg kwetsbare, hulpbehoevende, veelal oudere en chronisch zieke patiënten. Ik sta ook voor een innovatieve en meer pluriforme manier waarop dit vak in de nabije toekomst moet worden bedreven; het waarom daarvan zal U duidelijk worden.

Toen ik meer dan 20 jaar geleden voor de verpleeghuisgeneeskunde koos, verklaarden velen mij voor gek. 'Wat is dat nou voor een vakgebied?', 'welke eer is daar nu voor zowel patiënt als dokter te behalen?', 'je belandt in het afvalputje van de medische wereld' en 'wie wil en gaat er nu in godsnaam werken in een verpleeghuis?!' Het wordt nog gekker als je opmerkingen hoort zoals: 'Wie wil er nou toch bejaardenarts worden?' en, luistert $U$ ook goed naar deze...., 'Nee maar, ...je zult een echte condolerend arts worden!"

Ouderdom en zorg voor fragiele, hulpbehoevende ouderen hebben in ons land geen hoog aanzien. Het bezingen van de ultieme aspecten van het bereiken van een hoge leeftijd en het verheerlijken van de wijsheid die toch meestal komt met de jaren, is slechts weinigen gegeven. Nee, oud is niet 'in'; oud betekent vaak dat iemand echt heeft afgedaan, niet meer productief is voor de samenleving; ja zelfs eerder een dure last is...!

Ook studenten staan niet te trappelen van enthousiasme als je hun belangstelling peilt voor de medische zorg in verpleeghuizen. Nee, verpleeghuisgeneeskunde staat maar laag in de medische pikorde en de care-sector is bovendien veel minder sexy dan de cure-sector. De afgestudeerde arts die voor de verpleeghuisgeneeskunde kiest, wordt bovendien vaak in de volgende onaantrekkelijke metafoor geplaatst, zoals weergegeven door van Beek in haar boekje 'MedimetaforenBeeldspraak in de geneeskunde:' 'ach wat zielig voor die jongen of dat meisje; ik dacht nog wel dat hij/zij zo goed kon leren...' .' 
U snapt natuurlijk wel dat ik zal proberen aan te tonen dat de meeste van deze ongenuanceerde uitingen volstrekt onterecht zijn en dat de verpleeghuisgeneeskunde veeleer voor zulke positieve uitdagingen staat in onze sterk vergrijzende samenleving, dat het uiteindelijk een zeer gewaardeerd, en herkenbaar vakgebied zal worden. Daar ben ik immers echt van overtuigd!

Het vakgebied heeft de afgelopen jaren ongetwijfeld extra geleden onder het feit dat de verpleeghuissector zelf regelmatig negatief in het publieke nieuws komt en het is daarmee rechtstreeks verbonden met het negatieve imago dat bijna vast gekoppeld lijkt aan de verpleeghuiszorg. Draai dat maar eens om... Het betreft immers een hardnekkig probleem!

Paul Froeling deed in 1998, in zijn inaugurele rede als bijzonder hoogleraar verpleeghuisgeneeskunde in Nijmegen, reeds gewag van de veelvuldig negatieve persuitingen over de verpleeghuiszorg en datzelfde herhaalde zijn opvolger Raymond Koopmans in zijn rede in 2005. ${ }^{2,3}$

Vandaag wil ik bewust niet opnieuw extra aandacht besteden aan het vaak meedogenloos publiekelijk neersabelen van de verpleeghuiszorg, maar wel ingaan op de lessen die met name de verpleeghuisgeneeskunde daaruit zou kunnen trekken.

Dan gaat het natuurlijk over de kwaliteit van de verpleeghuiszorg enerzijds en van de verpleeghuisgeneeskunde anderzijds en voorts, over hoe de actuele transformatiefase waarin de ouderenzorg nu verkeert, gebruikt kan worden om doembeelden te laten verdwijnen en kwetsbare ouderen in onze samenleving het gevoel te geven dat ze zich in de toekomst daadwerkelijk veilig kunnen voelen als ze noodgedwongen langdurig formele (medische) zorg nodig hebben.

In deze rede komen de volgende onderwerpen aan bod.

Allereerst zal vanuit de historie naar de toekomst toe een beeld geschetst worden van de verpleeghuiszorg en in het verlengde daarvan natuurlijk van het vakgebied van de verpleeghuisgeneeskunde.

De positionering en doorontwikkeling van een vakgebied, dat zo sterk met de dagelijkse zorg praktijk verweven is, vereist een wetenschappelijke onderbouwing, die niet alleen evidence based is maar ook value based. Met dat laatste bedoel ik dat de inbedding en uitstraling van het vakgebied tot stand komen in nauwe wisselwerking met 
die dagelijkse zorgpraktijk en ook aansluiten op de ontwikkelingen die daarin plaatsvinden. En ook, dat het vakgebied oog heeft voor de daadwerkelijke appreciatie van evidence based aspecten door de beroepsgroep zelf, als ook door de patiënten die ermee te maken krijgen en tenslotte dat de doelmatigheid evenzeer niet uit het oog verloren wordt. Om de continuïteit van een vakgebied te waarborgen, moet tenslotte de opgedane kennis uitgedragen worden via relevante onderwijsactiviteiten, die ervoor zorgen dat er professionals blijven komen, die ook voor de continuiteit van het vakgebied zorgen.

Derhalve, zult $U$ van mij ook horen hoe we onderwijs en onderzoek in de verpleeghuisgeneeskunde in en vanuit de Universiteit Maastricht gestalte zullen geven. 


\section{Verpleeghuiszorg en verpleeghuisgeneeskunde vanuit de historie}

\section{Ouderenzorg; van thuiszorg tot verpleeghuiszorg}

Vroeger werden mensen oud in hun eigen leefomgeving, in het verband van de familie, het dorp en de kerkelijke gemeenschap. Ze werden oud in een leefwereld waarmee ze vertrouwd waren, waar hun wortels en relaties lagen en waarmee hun identiteit verbonden was.

De Nederlandse gezondheidszorg leek daarbij tot en met de eerste helft van de vorige eeuw, eenvoudig in elkaar te zitten. Door religieuze of humanistische motieven gedreven, begonnen huisartsen zich te vestigen en riepen religieuze groeperingen en notabelen stichtingen in het leven die ziekenhuizen bouwden. De congregaties stichtten kruisverenigingen en ook kwamen er consultatiebureaus.

Voor hulpbehoevende ouderen, gehandicapten en chronisch zieken, die om wat voor reden dan ook niet in hun eigen leefomgeving verzorgd konden worden, ontstonden collectieve oorden, waaronder gestichten, gasthuizen, rusthuizen etc. In die fase voerde de charitas nog duidelijk de boventoon. Later kwamen er steeds meer en ook meer specifieke zorginstellingen. De wereld van tehuizen ontwikkelde zich in de loop van een eeuw tot een geheel van moderne, professionele zorg- en verpleeginstellingen. Nederland was voorwaar trots op de geavanceerde wereld van het professionele instituut.

Zo kwamen er in de chronische zorg aparte instellingen voor verstandelijk gehandicapten en ook verpleeghuizen voor uitbehandelde patiënten, waarvoor in het ziekenhuis geen plaats meer was. In de tweede helft van de afgelopen eeuw, is onze gezondheidszorg mede door de welvaart in hoog tempo uitgebreid. Dat gold niet alleen voor de cure-sector, waarin door de steeds maar groeiende medisch- technische ontwikkelingen talloze nieuwe behandelmogelijkheden beschikbaar kwamen en er veel vooruitgang geboekt werd in het adequaat, snel en steeds meer ambulant behandelen van verschillende ziekten.

Langzaamaan privatiseerden ook de verschillende instellingen voor chronische zorg met als hoogtepunt de komst van de AWBZ in 1968. Onder het regiem van de AWBZ kregen de diverse vormen van chronische zorg de mogelijkheid fors uit te dijen, te differentiëren en te professionaliseren. 4

De thuiszorg ontwikkelde zich progressief en in de ouderenzorg ontstond, in een tijdperk waarin van echte ketenzorg nog geen sprake was, een schakeling van zorgaanbieders, waarvan op zijn minst 
theoretisch aangenomen mocht worden dat ze elkaar completeerden: thuiszorg - aanleunzorg - verzorgingshuiszorg - verpleeghuiszorg én ziekenhuiszorg. ${ }^{5}$

Hulpbehoevende ouderen die nog thuis wonen kunnen gebruik maken van informele zorg, particuliere hulp of van professionele thuiszorg. De vergrijzing van de samenleving heeft er inmiddels voor gezorgd dat ouderen voor de thuiszorgorganisaties de grootste doelgroep zijn. Indien de zorgbehoefte toeneemt en daarmee de behoefte aan beschermd wonen met zorggarantie, kan de oudere kiezen voor een aanleunwoning bij een verzorgingshuis, voor een woning bij een steunpunt of voor een woning in een voor ouderen gebouwd wooncomplex. Deze voorzieningen zijn in feite gepositioneerd in het tussengebied tussen zelfstandig wonen en intramuraal verblijf. ${ }^{6}$

Bewoners van aanleunwoningen kunnen terugvallen op de zorgservice/infrastructuur van het verzorgingshuis. Bewoners van woningen rondom een steunpunt maken gebruik van dienstverlening, die gestalte krijgt vanuit het steunpunt, waarin welzijnsruimten aanwezig zijn en van waaruit soms ook, via onderlinge samenwerking tussen de eerstelijns zorg en een in de buurt gelegen verzorgingshuis, zorg wordt verleend. Steunpunten, zijn voorlopers geweest van de tegenwoordig steeds vaker gebouwde moderne wooncomplexen voor ouderen. Het betreft voor ouderen toegankelijke en geschikte appartementencomplexen, bedoeld voor permanent verblijf, waarvan de bewoners behoefte hebben aan een combinatie van beschermd wonen en zorggarantie. Daartoe is in het complex veelal ook een basale zorginfrastructuur aanwezig in verband met de bundeling van wonen en zorg. De zorgverlening geschiedt door een verzorgingshuis of verpleeghuis, een thuiszorgorganisatie of door beiden. Tegenwoordig differentieert het zorgservice/aanbod van woonzorgcomplexen nog sterker, maar daarop wordt later verder ingegaan.

Indien de zorgbehoefte nog meer groeit, kan gekozen worden voor opname in een verzorgingshuis of verpleeghuis.

Het verzorgingshuis is bedoeld voor ouderen die een zodanige mate van geestelijke en lichamelijke hulpbehoevendheid hebben bereikt, dat zij eigenlijk continue aandacht nodig zouden hebben van de aanwezige extramurale voorzieningen, waardoor de grenzen van die hulpverlening zouden worden overschreden. De doelstelling van de 
huidige verzorgingshuizen kan worden omschreven als het bieden van een ondersteunend woonmilieu voor verzorgingsbehoevende ouderen. Veel verzorgingshuizen zijn gebouwd in de 60-er en 70 -er jaren van de vorige eeuw; de bewoner heeft er de beschikking over een 1 kamer appartement metwoon/slaapgelegenheid en een kleine sanitaire ruimte. De intramurale kernfuncties van het verzorgingshuis zijn: de zorgfunctie (verzorging en verpleging), de woonfunctie, de sociaal/culturele en recreatieve functie en de begeleidingsfunctie. Het hedendaagse verzorgingshuis heeft daarnaast ook een semimurale functie; er wordt dagopvang en/of dagverzorging geboden aan nog thuiswonende ouderen, die al dan niet op de wachtlijst voor het verzorgingshuis staan. Het voornaamste doel daarvan is meestal ontlasting van de informele en formele zorg die reeds aan huis plaatsvindt. In dat kader bieden veel verzorgingshuizen ook mogelijkheden voor tijdelijke opname.

Vanuit verzorgingshuizen wordt tegenwoordig eveneens extramurale zorg (w.o. huishoudelijke ondersteuning, verzorging/ verpleging, alarmering) en dienstverlening (w.o. maaltijdservice en welzijnsactiviteiten) verleend aan ouderen in aanleuncomplexen en in de wijk.4,5,7

De gemiddelde leeftijd van de (intramurale) verzorgingshuisbewoners is de afgelopen decennia toegenomen. Het merendeel is op dit moment ouder dan 85 jaar. De validiteit van de bewoners is sinds 1965 sterk afgenomen. Door de vergrijzing en de groei van de thuiszorg zijn mensen als ze uiteindelijk worden opgenomen ook ouder en behoeven ze meer en vaak ook specifiekere zorg dan vroeger. Dit alles leidt tot een toename van de zorgzwaarte binnen het verzorgingshuis. Had het verzorgingshuis in het begin van de tachtiger jaren nog voornamelijk een woonfunctie, inmiddels is dat primair een zorgfunctie geworden. Daarbij heeft op dit moment zeker $30 \%$ van de bewoners een verpleeghuisindicatie en wordt ongeveer $80 \%$ van de verpleeghuiszorg buiten de muren verstrekt aan verzorgingshuisbewoners met een verpleeghuisindicatie. ${ }^{4}$ Voor de meeste bewoners is het verzorgingshuis hun laatste woonomgeving.

Het verpleeghuis is een instelling van gezondheidszorg waar verpleegkundige, medische, paramedische en psychosociale zorg en begeleiding worden geboden aan mensen die thuis of in het verzorgingshuis niet meer adequaat geholpen kunnen worden. Verpleeghuiszorg wordt geleverd in drie soorten verpleeghuizen (somatische, psychogeriatrische en gecombineerde verpleeghuizen). 
In totaal zijn er nu ongeveer 345 verpleeghuizen met 27.000 somatische bedden en 36.000 psychogeriatrische bedden. Veruit het merendeel van deze 63.000 verpleeghuisbedden (jaar: 2004) komt ten goede aan ouderen, van wie de meerderheid ouder is dan 80 jaar. ${ }^{8,9}$ Veel patiënten verblijven nog op meerbedskamers. Hoofddiagnosen bij opgenomen somatische patiënten, die in de meerderheid van de gevallen vanuit het ziekenhuis worden opgenomen, zijn cerebrovasculaire aandoeningen, status na heupoperatie, andere orthopedische ingrepen of amputatie en ziekten van het centrale zenuwstelsel, w.o. de ziekte van Parkinson. De hoofddiagnose bij psychogeriatrische patiënten bestaat in veruit de meeste gevallen uit de verschillende verschijningsvormen van het dementiesyndroom. Psychogeriatrische patiënten komen voornamelijk vanuit de thuissituatie.

Een aanzien lijk deel van de somatische patiënten gaat na een gemiddelde revalidatieduur van 6 maanden weer terug naar de eigen woonomgeving. Voor definitief opgenomen somatische patiënten en voor bijna alle psychogeriatrische patiënten is het verpleeghuis het laatste station (gemiddelde verblijfsduur tot aan overlijden tegenwoordig ongeveer een jaar). ${ }^{9}$

Vanuit het verpleeghuis wordt aan somatische en psychogeriatrische patiënten ook de mogelijkheid tot dagbehandeling geboden; veelal ter voorkoming of uitstel van een verpleeghuisopname en ter ontlasting van de thuissituatie. De capaciteit van deze semimurale functie van het verpleeghuis is sinds de 70-er jaren fors gegroeid (2004: 6100 plaatsen). Instroom op de dagbehandeling geschiedt voornamelijk vanuit de thuissituatie. De dagbehandeling functioneert deels als substituut en deels als "wachtkamer" voor het verpleeghuis. ${ }^{10}$

Capaciteitstekorten van verpleeghuizen hebben er niet alleen toe geleid dat er de laatste 15 jaar meer dagbehandelingsplaatsen zijn gekomen, maar ook dat het fenomeen "verpleeghuiszorg buiten de muren" (extramurale verpleeghuiszorg) zich ontwikkeld heeft; vooralsnog met name in verzorgingshuizen, maar geleidelijk aan ook meer en meer bij patiënten thuis.9,11

Het zorgaanbod van verpleeghuizen betreft, naast observatie en diagnostiek de zorgfuncties revalidatie/reactivering, langdurige zorg, bijzondere zorg, tijdelijke opname en crisisopvang. Deze functies zijn elk uit de zorgelementen verpleging, verzorging, behandeling en begeleiding opgebouwd,waarbij de accenten per zorgfunctie uiteraard anders liggen.., 9 
Verpleeghuiszorg wordt ook wel aangeduid met de term CLSM-zorg; het betreft een continue, langdurige, systematische en multidisciplinaire zorgverlening, die verleend wordt door teams van verzorgende, verpleegkundige, paramedische en psychosociale professionals, werkend onder regie van verpleeghuisartsen. De verpleeghuisgeneeskunde is daarbij in ons land, als enige ter wereld, al wat langer een specifiek erkend medisch specialisme. ${ }^{9}$

Maar hoe heeft zich dat specialisme dan ontwikkeld?

\section{Verpleeghuisgeneeskunde}

Alvorens de professionele medische hulp aan de oude, gebrekkige, langdurig of ongeneeslijk zieke medemens te kunnen aanmerken als verpleeghuisgeneeskunde, als een onderdeel van onze specialistisch denkende geneeskunde, moeten we ons realiseren dat daar een lange weg aan vooraf is gegaan. Waar zich bij de reguliere geneeskunde bepaalde terreinen, of onderdelen daarvan, door een zekere verdieping onderscheiden van de algemene, de generalistische, geneeskunde, is dit bij de verpleeghuisgeneeskunde enigszins anders gegaan. De wortels van de verpleeghuisgeneeskunde moeten we namelijk ook deels zoeken in de wereld van de zorg.

In de oorspronkelijke gestichten, de voorlopers van de huidige verpleeghuizen lagen voornamelijk oudere patiënten die in het ziekenhuis uitbehandeld waren maar niet meer naar hun eigen woonomgeving terug konden keren, ofwel patiënten die primair vanuit hun eigen leefomgeving waren opgenomen omdat ze door verschillende redenen echt niet meer thuis konden blijven. Aanvankelijk waren deze instellingen nog ongedifferentieerd in inrichting en organisatie. Terminale patiënten, ongeneeslijk zieken, dementerenden, ze lagen zo maar door elkaar; bij elkaar gebracht om hun overlijden af te wachten. Verzorging en verpleging waren het hoofddoel. Wel kwam er incidenteel een plaatselijke huisarts om de "broodnodige" hulp te bieden; niet in het perspectief van genezing, maar vooral om het lijden te verlichten, cq. de wettelijk verplichte handelingen te verrichten in geval van overlijden. ${ }^{12,13}$

Later werd de betrokkenheid van de arts bij de instelling weliswaar groter en ontstonden de eerste formele dienstverbanden, vaak van huisartsen die met hun praktijk gestopt waren en ter overbrugging van de laatste jaren tot hun pensioen, een dienstverband met een instelling aangingen. Toch veranderde hun taak als medicus aanvankelijk nauwelijks. Hun bemoeienissen richtten zich veeleer op materiële zaken, 
zoals de gebouwen en hun inrichting. ${ }^{13}$

Langzamerhand echter werd het verpleegkundige aspect minder vrijblijvend. Allengs ging het verplegend personeel de in het huis verblijvende zieke mens met andere ogen zien; niet wat er allemaal mis was, maar ook wat er nog te behalen viel aan welzijn, ondanks de doorgaans sombere vooruitzichten. In plaats van een afwachtende houding aan te nemen; letterlijk pappen en nathouden en maar wachten tot de dood er op volgde, begon men het over een andere boeg te gooien. ${ }^{13,14}$

Ook al was men ervan overtuigd dat er van een volledig herstel geen sprake meer kon zijn, men kreeg veel meer oog voor 'het toevoegen van leven aan de dagen', dan voor 'dagen aan het leven'. Duidelijk was echter, dat hier meer voor nodig was dan verpleging alleen en dat daarvoor gekwalificeerde, professionele krachten aangetrokken moesten worden. Dat was het begin van de integrale benadering die de totale verpleeghuiszorg zo kenmerkt.

Ook de arts kon hier niet aan de zijlijn blijven staan. Er werden een bredere kijk en inbreng van hem verwacht dan alleen voor de puur medische aangelegenheden. Holistisch bezig zijn binnen het verpleeghuis vereiste immers een medisch professional die op adequate wijze, als primus inter pares, met zijn medewerkers plannen maakte ten behoeve van de patiënt, die behandelingen voorstelde voor de gewenste opties en vertrouwen toonde in ieders deskundigheid en inzet. Er mocht dan ook terecht van hem verwacht worden dat hij zich in zijn vakgebied zo breed mogelijk oriënteerde en zodoende ook voldoende inzicht verwierf in de paramedische en psychosociale kanten van de behandeling. ${ }^{15}$

De realisatie van een dergelijke visie ging gepaard met een inbedding in een multidisciplinair kader. Naast de beginnende professionalisering van de verpleeghuisarts in wording, leidde dat tot het werken in teamverband met verpleegkundigen, verzorgenden, paramedici, psychologen, maatschappelijk werkers, geestelijk verzorgers etc.

Aanvankelijk kende deze werkwijze nog een tamelijk incidenteel karakter, doch deze werd expliciet en gestructureerd toen in 1972 de Nederlandse Vereniging van Verpleeghuisartsen (NVVA) werd opgericht. In een zich spoedig vormende nauwe band tussen de beroepsgenoten gold als eerste keuze de professionalisering van hun werkzaamheden door onderlinge contacten, waarbij voorop stond dat de verdere beroepsontwikkeling slechts tot resultaat zou leiden als deze plaats zou vinden op basis van een gedegen, wetenschappelijke studie van de ziekte en zorgproblematiek van langdurig zieken en bejaarden. ${ }^{16}$ Uiteraard beseften de betrokkenen 
dat zij dit alles niet op eigen kracht konden bereiken en dat hieraan ook vanuit een specifieke opleiding de nodige aandacht besteed zou moeten worden.

Slechts een fundamentele aanpak zou hier dus succes kunnen hebben, waarbij op de eerste plaats gedacht werd aan de officiële erkenning en registratie van het beroep van verpleeghuisarts; een en ander te verwezenlijken na de totstandkoming van een postacademische opleiding daartoe. Die zou plaats moeten vinden in samenhang met relevant wetenschappelijk onderzoek; onderzoek dus in het kader van de functie van de verpleeghuisarts, voor de patiënt in het verpleeghuis, en over diens hoofd heen, ten dele ook voor diens lotgenoten "buitenshuis" (dus extramuraal); lotgenoten waarvan het aantal bij onze dubbel vergrijzende bevolking met de dag groeit. Dit streven leidde in 1980 tot de eerste universitaire leerstoel Verpleeghuisgeneeskunde in Nijmegen, in 1989 tot de eerste specialisatie-opleiding tot verpleeghuisarts in Amsterdam en in 1990 tot de officiële erkenning van het vakgebied met de opening van een apart register voor verpleeghuisartsen, dat op dit moment meer dan 1400 geregistreerde verpleeghuisartsen kent.

Inmiddels zijn er ook vervolgopleidingen tot verpleeghuisarts aan de universiteiten van Nijmegen en Leiden.

Maastricht is de volgende universitaire stad van waaruit het vakgebied zich verder kan en zal ontplooien.

Met de erkenning van de verpleeghuisgeneeskunde ontstond in Nederland een unieke medische as of beter triade voor fragiele en hulpbehoevende ouderen, bestaande uit de huisarts, verpleeghuisarts en klinisch geriater (op sommige plaatsen de internist ouderen), waar nodig aangevuld met de ouderenpsychiater.

Eigenlijk een kwartet dus, met potentie voor de oudere patiënt!

\section{Wat nu kan die verpleeghuisarts eigenlijk?}

Als $u$ dat tot in detail wilt weten, kunt $u$ er de erg zakelijke opsomming van alle taken, beschreven in de meest recente nota Takenpakket van de NVVA uit 2003, op naslaan. Samengevat vermeldt deze nota dat de kerncompetentie van de verpleeghuisarts is, dat deze zijn medischgeriatrische deskundigheid verbindt met deskundigheid op het gebied van zorgdiagnostiek, zorgprognostiek en zorgmanagement. Daarvoor gebruikt de verpleeghuisarts een integrale, probleemgeoriënteerde methode van diagnostiek en interventies op het niveau van ziekten en ziektegevolgen en ook van het zorgsysteem. Het vakgebied kenmerkt zich derhalve door een integrale wijze van kijken naar de patiënt en 
zijn/haar zorgsysteem, met inachtneming van diens huidige toestand, voorgeschiedenis, persoonlijkheid en ook sociale en materiële omgeving. Niet alleen de ziekten, maar vooral de gevolgen van die ziekten voor de functionele autonomie en de kwaliteit van leven van de patiënt in relatie tot diens zorgsysteem bepalen de focus van deze benadering. ${ }^{17}$

Cools, inmiddels nestor onder de hoogleraren verpleeghuisgeneeskunde, beschreef het handelen van de verpleeghuisarts eind vorig jaar in Medisch Contact echter op een veel prachtiger wijze en ik citeer hem daarom letterlijk: ${ }^{18}$

....'Ook al ordent de ziektegeschiedenis symptomen en diagnosen in de tijd, de actuele gezondheidsproblemen zijn geen optelsom van deze multi-/comorbiditeit met daaraan gerelateerde 'zorgzwaarten'. ledere verpleeghuispatiënt heeft een eigen 'wanordelijk' syndroom van dagelijks variërende en verschuivende symptomen, dat in geen enkel leerboek staat en nauwelijks is te ontrafelen in elkaar niet overlappende ziekte-entiteiten. Bij gebrek aan toepasbare diagnostiek zitten er vaak 'vermoedelijke' diagnosen tussen. Fysieke problemen worden niet alleen op orgaanniveau, maar tegelijkertijd ook als 'bijdrage' aan (psychiatrische) syndromen aangepakt. Overlappende syndromen vragen om een aanpak in de goede volgorde.

Voortdurend zoekt de verpleeghuisarts met de patiënt en familie naar de juiste aanpak van het 'wanordelijk' syndroom. Ouderen weten immers wat belangrijk voor henzelf is. Zij beseffen dat persoonlijke belangen zijn verstrengeld met die van hun (bloed)verwanten en dat professionele belangenbehartiging wederkerig is. Kwetsbare ouderen willen wel graag, maar durven vaak niet de regie over het eigen leven te behouden. Ouderen met complexe gezondheidsproblemen verlangen niet alleen verzorging, wooncomfort, participatie en welbevinden, maar vooral ook vrijwaring van hinderlijke klachten, ook in de laatste levensweken. De meesten blijven hopen op een 'beter' perspectief.

Bij elke verpleeghuisopname inventariseert de verpleeghuisarts niet alleen het 'wanordelijk' syndroom, maar ook nadelige interacties, ongewenste (neven)effecten en inefficiënte logistiek van de geleverde gefragmenteerde verzorging, verpleging en (para)medische behandelingen. Het geriatrisch saneren hiervan leidt tot een aangepast en kosteneffectief behandel-/ zorgleefplan, inclusief verschuiving van symptomen en mogelijke onderbehandeling.

Ga bijvoorbeeld maar na welke medicatie moet worden gestaakt om bijwerkingen als hinderlijke obstipatie, urine-incontinentie, gebrek aan 
eetlust, droge mond, duizeligheid bij opstaan en lopen, slaapstoornis of wisselende verwardheid te verhelpen. Weeg dit af tegen de mogelijke gevolgen voor cardiovasculaire, neurologisch-psychiatrische, gastroenterologische en urologische aandoeningen en relateer dit aan de invloed van gestaag afnemende reservecapaciteit van organen op het voortgaande ziekteverloop.

Vanzelfsprekend wordt dit voorlopige complexe behandelplan intensief gecontroleerd.

Cools meldt voorts dat de verpleeghuisarts binnen de muren van het verpleeghuis de 24 -uursvariaties in de totale behandeling en verpleging reguleert, om voor iedere individuele patiënt 'het geheel van een hoger en veiliger niveau van relevantie te voorzien dan de som der fragmenten'. Het is duidelijk dat daarbij ook het enthousiasme, de motivatie en de specialisatie van het multidisciplinaire zorgteam een rol spelen.

Als $u$ dit zo hoort, moet $u$ toch met me eens zijn dat dit een prachtig en dankbaar vak is!

Het belang van goede en meer continue medische zorg voor verpleeghuispatiënten wordt ook internationaal herkend en onderschreven vanwege het tijdsbeslag dat verpleeghuispatiënten leggen op de medische zorg, het frequente aantal medische consultaties dat zij vereisen en aan de daarbij in feite niet passende logistiek van de huisarts. Desalniettemin is Nederland vooralsnog het enige land waar de medische zorg in verpleeghuizen een eigen status heeft verworven 4,9

In de jaren na 1990 heeft de professionalisering van de verpleeghuisgeneeskunde zich doorgezet, zijn de eerste richtlijnen voor het verpleeghuisgeneeskundig handelen verschenen en is in de praktijk ook duidelijk geworden dat relevante aspecten van de verpleeghuiszorg en de verpleeghuisgeneeskunde bruikbaar zijn in de eerstelijn, ten behoeve van kwetsbare ouderen en chronisch zieken die nog in hun eigen omgeving of in het verzorgingshuis verblijven én zelfs ook in het ziekenhuis. Daartoe kan de verpleeghuisarts, naast zijn rol als hoofdbehandelaar in het verpleeghuis, elders ook als medebehandelaar of consulent optreden.

Desalniettemin is een brede extramurale inbreng van de verpleeghuisgeneeskunde vooralsnog niet gerealiseerd en moeten we bovendien constateren dat we nog niet het optimale rendement uit het hierboven genoemde medische kwartet gehaald hebben. De afzonderlijke specialismen werken nog teveel vanuit hun eigen denkwereld en bastion. 
Het werken buiten de muren van het verpleeghuis vereist bovendien aanvullende extramurale competenties, o.a. op het gebied van de interdisciplinaire samenwerking.

Met ingang van 2006 zijn de verpleeghuisgeneeskunde en de (oorspronkelijk niet erkende) sociale geriatrie opgegaan in een vernieuwd en breder geriatrisch specialisme, dat opleidt tot een 'verpleeghuisarts nieuwe stijl' met duidelijk bredere competenties. De oorspronkelijk voornamelijk intramurale kennis en vaardigheden van deverpleeghuisarts worden nu uitgebreid met de ambulante kennis en vaardigheden van de sociaal geriater, die van oudsher veelal werkzaam is vanuit de GGZ en die voornamelijk in de eerstelijn mensen met psychogeriatrische en gerontopsychiatrische problematiek ondersteunt

De vervolgopleiding is recentelijk ook uitgebreid van 2 naar 3 jaar en assistenten in opleiding worden niet alleen meer in het verpleeghuis opgeleid maar ook in GGZ-instellingen, ziekenhuizen en de huisartspraktijk.

Daarmee wordt als het ware vorm gegeven aan een vernieuwd en verbreed medisch generalistisch vakgebied voor fragiele ouderen en mensen met een chronische ziekte en kan het "gerenoveerde specialisme" hiermee vol vertrouwen naar de toekomst kijken.

De erkenning en verspreiding van het vakgebied nationaal en wellicht ook internationaal zal echter nader gestaafd moeten worden door resultaten van verpleeghuisgeneeskundig onderzoek. En hier is zeker nog een slag te maken en te winnen, zoals verderop in deze rede zal blijken. Uiteindelijk zal het vak dan pas echt breed gekend zijn.

\section{Waar staan we op dit moment?}

De beschreven voorzieningen en ook de verschillende medische specialismen in de ouderenzorg hebben zich, afzonderlijk van elkaar, de afgelopen decennia kwantitatief en kwalitatief sterk ontwikkeld. Niet alleen is de capaciteit van de onderscheiden intramurale, semimurale en extramurale zorgvoorzieningen progressief toegenomen; ook de variëteit en de kwaliteit van het steeds verder gedifferentieerde zorgaanbod heeft zich sterk ontwikkeld. Dit geschiedde deels onder invloed van wetgeving, zoals de Kwaliteitswet Zorginstellingen (1996) en deels vanuit intrinsieke motieven. Sinds begin negentiger jaren van de vorige eeuw is het scala aan professionals en daarmee de multidisciplinaire deskundigheid fors toegenomen en heeft ook de verpleegkundige basiszorg een kwaliteitsimpuls gekregen. Nieuwe disciplines en subspecialisaties ontstonden (w.o. gespecialiseerde 
paramedici, psychologen, verpleegkundigen en zoals genoemd de verpleeghuisartsen).

De verschillende beroepsgroepen professionaliseerden sterk en ook protocollair werken lijkt langzaamaan gemeengoed geworden.

De positie van de patiënt kreeg meer aandacht, mede onder invloed van een aantal wetten, waaronder de Wet Medezeggenschap Cliënten Zorginstelingen (WMCZ, 1996), de Wet op de Geneeskundige Behandelovereenkomst (WGBO,1995) en de wet Bijzondere Opnemingen in Psychiatrische Ziekenhuizen (BOPZ, 1992).

Ook traden voorzichtig innovatieve zorgontwikkelingen op, voornamelijk in de vorm van substitutie van bestaande intramurale zorgvormen (bijv.: dagverzorging, dagbehandeling en extramurale zorgprojecten). Zij kwamen grotendeels tot stand door capaciteitstekorten (dus wachtlijsten) en door het overheidsbeleid dat een ongebreidelde groei van de intramurale voorzieningen wilde ontmoedigen en voortdurend op de kostenontwikkelingen bleef wijzen.

Opvallend is dat deze innovatieve ontwikkelingen vooralsnog primair hebben plaatsvonden binnen en vanuit afzonderlijke ouderenzorgorganisaties zelf. Daar waar ook samenwerking tussen ambulante en institutionele zorgaanbieders of tussen verschillende institutionele zorgaanbieders tot stand is gekomen, hebben, vanuit zorgmarktoverwegingen, voornamelijk strategische en financiële motieven een rol gespeeld.

Bovendien is tot op de dag van vandaag ook de scheiding tussen de cure- en de care-sector nog navrant, waardoor ook de transmurale samenwerking tussen bijvoorbeeld deverschillende medische disciplines, die werkzaam zijn voor ouderen, maar moeizaam van de grond komt. De gesprekken over 'samenwerking'zijn daardoor hoofdzakelijk gegaan over de 'afscheiding' van elkaars terreinen...!

Het denken in ketenzorg- en netwerkzorgmodaliteiten en het zoeken naar structurele oplossingen voor de frequente problemen, die gepaard gaan met transities van kwetsbare oude patiënten tussen verschillende onderdelen van ons gezondheidszorgsysteem is pas de laatste jaren opgekomen en in de praktijk nog niet op grote schaal gerealiseerd.19

Dit alles heeft geleid tot een complex en moeilijk te doorgronden en te beheersen, alsmaar uitdijend gezondheidszorgsysteem dat nog veelal aanbodgericht en zelfs paternalistisch is; en dat gekenmerkt wordt door een gebrek aan complementariteit en continuïteit tussen de diverse zorgonderdelen. ${ }^{20}$ 
Voor de patiënt is het systeem vaak moeilijk toegankelijk en biedt het weinig echte keuzemogelijkheden. Dat geldt temeer voor kwetsbare oudere patiënten, veelal chronische patiënten, voor wie stoornis, beperking en handicap geen incident zijn, maar een toestand die blijvend een invaliderend stempel zet op hun geschonden bestaan. Velen van hen ervaren dagelijks hoe sterk ze afhankelijk zijn van anderen en onderworpen aan de vele regels van een vaak ondoorzichtig en bureaucratisch stelsel, hetgeen hun rol van gebrekkige nog eens extra bekrachtigt. Niet zelden 'verdwalen' ze dan ook in onze gezondheidszorg. ${ }^{21}$

Sommigen van hen zeggen in dit verband dan ook schamper: 'het is toch maar goed, dat je dood gaat, want anders ga je er wel aan'....

\section{Het verpleeghuis ter discussie}

Ook het bestaansrecht van het verpleeghuis als institutie staat op dit moment ter discussie, waarbij we overigens in mijn ogen soms te snel de goede aspecten van de verpleeghuiszorg, zoals die al jaren met veel inzet geleverd wordt, uit het oog verliezen. Zeker ook, omdat vanuit diverse andere landen in de wereld nog vaak jaloers gekeken wordt naar onze oorspronkelijke AWBZ en naar hetgeen de verpleeghuissector de afgelopen decennia vanuit deze AWBZ heeft kunnen opbouwen.

Het publieke imago van opberghuis c.q. sterfhuis en ook de frequente berichtgevingoverslechtekwaliteitvanzorghebben deverpleeghuissector de laatste jaren echter, zoals gememoreerd, veel kwaad gedaan.

Niettemin zijn de woon- en welzijnscomponent van het verpleeghuis duidelijk achter gebleven in ontwikkeling, iets waarvan de patiënten voor wie het verpleeghuis vaak de laatste woonomgeving is zondermeer te lijden hebben. We komen dan meteen bij het grootste nadeel van het traditionele verpleeghuis als instituut, te weten de vaak nog sterk ziekenhuisachtige omgeving (met een groot gebrek aan privacy) en het hieraan gekoppelde strakke institutionele regime. Weliswaar heeft dit probleem al enige tijd de aandacht, maar zowel het omgevingsaspect als het feit dat ook andere negatieve kwaliteitsaspecten samenhangen met de wijze waarop een institutioneel regime nu eenmaal werkt, nopen steeds dringender tot verandering.

Bovendien zijn er een aantal zeer relevante aspecten waaraan de basale verpleeghuiszorg en ook de verpleeghuisgeneeskunde meer aandacht zouden moeten besteden om tot een wenselijke verbetering van de kwaliteit van zorg te komen. Het betreft hier o.a. de wijze waarop in verpleeghuizen omgegaan wordt met frequent voorkomende medische en zorgproblemen zoals, decubitus, delier, depressie, incontinentie, 
ondervoeding, polyfarmacie, probleemgedrag, vallen en voortgeschreden orgaanfalen.

Uitdagingen derhalve om de verpleeghuisgeneeskundige en ook de verpleegkundige kwaliteit van werken te verbeteren. ${ }^{22}$

De status actualis van onze ouderenzorg verklaart dus voor een groot deel de roep om verandering, c.q. innovatie, die al langere tijd te horen is in en vanuit de ouderenzorg en ouderengeneeskunde in het algemeen en de verpleeghuiszorg en verpleeghuisgeneeskunde in het bijzonder. Verandering die nodig is vanuit macro-economisch perspectief en niet in de laatste plaats ook vanuit het perspectief van de patiënt zelf.

De patiënt is tegenwoordig een cliënt en wil meer dan ooit zelf, óf met respectvolle ondersteuning, keuzes maken ten aanzien van de te ontvangen zorg en dienstverlening; én ook waar hij/zij deze wil ontvangen. 


\section{Het moet en zal anders in de toekomst}

In de ouderenzorg is, de afgelopen jaren, de roep om een meer vraaggestuurde, geïntegreerde zorg ('integrated care') steeds sterker geworden. Daarbij staat het streven naar een kwalitatief hoogstaande en patiëntgerichte zorg centraal en bovendien moet deze zorg passen bij de leefsituatie van de oudere zorgvrager en hem of haar in staat stellen om zo lang en zo normaal mogelijk te participeren in onze samenleving. Dit fenomeen wordt vermaatschappelijking van de zorg genoemd. ${ }^{21}$ Vermaatschappelijking van de zorg komt bijvoorbeeld tot uiting in een nieuwe uitkomstmaat voor de ouderenzorg. Lag het accent vroeger voornamelijk op de kwaliteit van de zorg, nu verschuift dat naar de kwaliteit van leven, in lichamelijk, psychisch en sociaal opzicht. Voor een optimale kwaliteit van leven blijft een kwalitatief verantwoorde (medische) zorg natuurlijk noodzakelijk, maar ook aspecten als zingeving, primair levensgeluk, behoud van autonomie, eigen leefomgeving, eigen leefwijze en eigen sociaal netwerk, en de gewenste maatschappelijke participatie zijn essentieel. Vermaatschappelijking van de zorg houdt niet alleen een kanteling naar een meer vraaggestuurde en genormaliseerde zorg in, maar betekent ook dat de traditionele intramurale zorg zal transformeren.

Zorgbehoevende ouderen willen zolang mogelijk als volwaardige burgers in de wijk wonen en niet afgezonderd worden in separate zorgkolommen. In de wijken van de toekomst wonen burgers met beperkingen en handicaps in de straat, te midden van burgers zonder beperkingen. Daardoor zal er in de woonwijken meer complexe zorgverlening vereist zijn, die niet meer primair intramuraal gegeven moet worden.

Technologische mogelijkheden en ontwikkelingen op medisch en verpleegkundig gebied maken de zorg immers minder afhankelijk van de locatie, zodat deze in toenemende mate ambulant of in de eigen woonomgeving verleend kan worden. Initiatieven om fragiele ouderen zo lang mogelijk in hun eigen woonomgeving te laten blijven, zijn reeds gestart in de jaren negentig van de vorige eeuw en in de loop van de jaren zijn er reeds opvallende veranderingen opgetreden in de verhouding tussen intramurale en extramurale zorg:4,8,23,24

- de gemiddelde ligduur in ziekenhuizen is fors teruggelopen;

- vanwege de intrinsieke doorontwikkeling van de thuiszorg zelf en de technologische ontwikkelingen is gespecialiseerde thuiszorg een reële optie geworden; 
- de huisartsgeneeskunde heeft zich ontwikkeld tot een meervoudig systeem van huisartsenzorg, waarin niet alleen op vele plekken meerdere huisartsen vanuit dezelfde praktijklocatie werkzaam zijn, met hier en daar al duidelijke taakdifferentiaties t.a.v. specifieke doelgroepen, maar hun werk wordt inmiddels ook versterkt en verdiept door praktijkondersteuners, praktijkverpleegkundigen etc;

- versterking en aanvulling van de thuiszorg kan al dan niet op complementaire wijze geschieden door extramuralisering van verzorgingshuiszorg en verpleeghuiszorg en ook zijn er gedifferentieerde mogelijkheden voor ambulante begeleiding van ouderen met psychiatrische en/of psychogeriatrische problematiek vanuit de GGZ;

- palliatief terminale zorg thuis in plaats van in een zorginstelling is voor veel ernstige zieke ouderen een reëel perspectief geworden;

- opname in verpleeghuizen en verzorgingshuizen wordt zolang mogelijk uitgesteld;

- substitutie van verpleeghuiszorg in het verzorgingshuis is een breed gerealiseerde voorziening geworden;

- er is inmiddels een breeds scala aan tussenvoorzieningen voor respijtzorg beschikbaar ter ontlasting van de zorg thuis; hiermee doelen we op: tijdelijke opname, dagverzorging en dagbehandeling en ook op projecten ter ondersteuning van de mantelzorg/informele zorg, wier fundamentele rol natuurlijk niet vergeten mag worden. Zonder adequate mantelzorg en/of andere informele zorg wordt het zo lang mogelijk thuis blijven van fragiele ouderen immers al snel tot een probleem, zeker als de zorgzwaarte progressief toeneemt. 25,26

Bij het zo lang mogelijk in de eigen woonomgeving blijven van fragiele ouderen zijn ook de gemeentelijke welzijnsorganisaties betrokken. Zij organiseren vaak in samenwerking met verzorgingshuizen en/ of verpleeghuizen de "tafeltje dek je maaltijden" en alarmering aan huis voor zorgbehoevende ouderen. Verder proberen ze via een scala aan activiteiten (w.o. meer bewegen voor ouderen, soosactiviteiten, computercursussen, voorlichtingsbijeenkomsten etc.) de betrokkenheid van nog thuiswonende gezonde en zieke ouderen bij het maatschappelijk gebeuren te bewerkstelligen. Daarnaast spelen vrijwilligersorganisaties een belangrijke rol bij de ondersteuning van zorgbehoevende ouderen en hun mantelzorgers/informele zorgers en beijveren ook de verschillende patiëntenverenigingen (vaak gekoppeld aan specifieke ziekten) en de 
belangenorganisaties voor patiënten (bijv. NPCF: Nederlandse Patiënten en Consumenten Federatie), zich ervoor om alles in het werk te stellen om fragiele ouderen zo lang mogelijk in hun eigen vertrouwde leefsituatie te handhaven.

Voor de woningcorporaties is de trend richting vermaatschappelijking natuurlijk ook een relevant aandachtspunt. Een groeiend aantal corporaties realiseert zich dan ook terdege dat de dubbele vergrijzing en de verregaande substitutie van zorg de kwantitatieve en kwalitatieve afstemming van woningen op de specifieke behoefte van ouderen dringend noodzakelijk maken; tenminste als we het zo lang mogelijk zelfstandig blijven wonen van ouderen, liefst in hun eigen omgeving, mogelijk willen maken. 6,7 Tenslotte zal de toepassing van domotica, dat is technologie thuis, in de toekomst ongetwijfeld ook een belangrijke rol spelen.

\section{Vermaatschappelijking en verbijzondering van de verpleeghuiszorg}

Verpleeghuizen richten met betrekking tot de vermaatschappelijking van de zorg al geruime tijd hun vizier buiten de eigen muren. Zo wordt er reeds sinds 1990 in toenemende mate aanvullende, extramurale verpleeghuiszorg geboden, aanvankelijk voornamelijk in verzorgingshuizen en later ook steeds meer bij chronische patiënten thuis. Het eerste heeft ertoe geleid dat het aantal verpleeghuisopnames vanuit verzorgingshuizen de laatste jaren drastisch is afgenomen. Het laatste, verpleeghuiszorg aan huis, geschiedt complementair aan de thuiszorg of volledig door het verpleeghuis zelf. Zo kunnen patiënten die eigenlijk een indicatie hebben voor opname in een verpleeghuis, langer thuis blijven.

De vermaatschappelijking van de verpleeghuiszorg krijgt ook gestalte door de steeds verder gaande zorgfunctiedifferentiatie (verbijzondering van de verpleeghuiszorg) die intramuraal optreedt. Dit blijkt onder andere uit de fors gegroeide herstel- en revalidatiefunctie, op grond waarvan steeds meer fragiele ouderen slechts tijdelijk opgenomen worden en na een herstelfase in een veel betere toestand weer naar hun eigen leefomgeving terugkeren. De revalidatie- en herstelzorgfunctie van het verpleeghuis voor patiënten met een status na CVA of orthopedische ingreep heeft zich de afgelopen 15 jaar sterk ontwikkeld. Het verpleeghuis neemt een niet meer weg te denken plaats in binnen de CVA-ketenzorg en er zijn talloze vedoprojecten orthopedie, waarin patiënten na een orthopedische ingreep versneld kunnen doorstromen (='vedo') naar het verpleeghuis en na behandeling 
aldaar weer naar huis. Deze gespecialiseerde institutionele zorgfunctie heeft daarmee dus ook een evident de-ïnstitutionaliserend effect. Naar verwachting zal de herstelzorgfunctie van het verpleeghuis zich sterk blijven doorontwikkelen de komende jaren omdat er door de steeds kortere ligduur in ziekenhuizen sprake zal zijn van een toenemende ziekenhuisverplaatste zorg richting de verpleeghuizen met een druk op de restauratieve en revaliderende overbruggingszorg richting de thuissituatie. De herstelzorgfunctie kan daarbij ook een rol spelen voor patiënten met bijvoorbeeld chronisch orgaanfalen, die tijdelijk multidisciplinaire herstelzorg nodig hebben na een periode van decompensatie van hun lichamelijke toestand.

Dan is er nog de expertise die in verpleeghuizen doorontwikkeld wordt op het gebied van de palliatieve zorg en die, in en vanuit de regionale netwerken voor palliatieve zorg, ingezet wordt ter ondersteuning van de eerstelijns zorg en daarmee ook bijdraagt aan het voorkómen van opname van terminale patiënten.

Verpleeghuisartsen, verpleeghuisparamedici (fysiothera peut, logopedist, diëtist en ergotherapeut) en verpleeghuispsychologen kunnen voorts consultatief een ondersteunende functie vervullen voor de huisarts en de thuiszorg, waarmee de zorg voor fragiele ouderen thuis ook een complementaire kwaliteitsimpuls kan krijgen.

Om de wijkfunctie van verpleeghuizen nog verder te verbreden en het langer in de eigen leefomgeving handhaven van kwetsbare ouderen te bevorderen, zien we voorts op dit moment steeds meer dat de vroegere, grotere hoofdlocaties, die primair een regionale functie hadden, afgebouwd worden tot kleinere centra met diverse typen van satellieten die regionaal mooi gespreid zijn als dependances of verpleegunits, of in de vorm van kleinschalige woonvormen. Deze satellieten kunnen separaat staan of gekoppeld zijn aan 'opgepluste verzorgingshuizen' of woonzorgcentra 'nieuwe stijl'. Met de laatste bedoelen we de op vele plaatsen verrijzende, gedifferentieerde dan wel niet gedifferentieerde, residentiële AWBZ-voorzieningen voor verpleging en verzorging (waar verzorgingshuiszorg en/of verpleeghuiszorg geboden wordt) met daaraan gekoppeld ook "ruime aanleunwoningen nieuwe stijl". Ze worden ook wel moderne woonzorgcomplexen genoemd; dat zijn geïntegreerde en levensloopbestendige woonzorgcentra, waarin en van waaruit alle vormen van zorg geboden kunnen worden en waarin zelfs eerstelijnsvoorzieningen zoals een huisartsenpraktijk, tandarts, apotheek etc. opgenomen kunnen zijn. ${ }^{21}$

Veel van deze nieuwe woonzorgcomplexen komen overigens tot stand 
vanuit zorgorganisaties die zowel verpleeghuizen als verzorgingshuizen bezitten en beide voorzieningen als het ware aan het innoveren en transformeren zijn.

De kleinschalige woonvormen die steeds meer op verschillende lokaties gebouwd worden (veelal in de buurt van bestaande instellingen dan wel in of rond nieuwere woonzorgcentra) bieden tegenwoordig plek aan gemiddeld 6 personen; meestal dementerende verpleeghuispatiënten. Men gaat ervan uit dat de kwaliteit van leven van deze doelgroep, door een kleinschalige, genormaliseerde woonvorm, fors vooruitgaat. 27,28

\section{Het verpleeghuis als instituut zelf}

Voor mij staat overigens buiten kijf dat ook het verpleeghuis als instituut NIET zal verdwijnen. Sommigen spreken van een in de toekomst overblijvend 'rest' - instituut.

Complete verbanning van de institutionele zorg en puur inzetten op community care blijken immers veelal een onhaalbare kaart te zijn. Ervaringen in andere landen (w.o. Denemarken) leren dit ook. Nee, het toekomstige verpleeghuis nieuwe stijl zal m.i. zelfs geen "rest"-instituut zijn, maar eerder een herkenbaar instituut of zorghuis met veel power en onderscheiding; zij het wel veelal kleiner van omvang dan nu.

De verpleeghuizen nieuwe stijl herbergen straks met name de reeds genoemde specifieke en bijzondere verpleeghuisfuncties, met als belangrijke exponent de revaliderende en reactiverende herstelzorg, maar ook de zorg voor specifieke doelgroepen zoals patiënten met niet-aangeboren hersenletsel (NAH), de ziekte van Huntington én patiënten met een behoefte aan zeer complexe somatische en/of psychogeriatrische zorg. Het zal duidelijk zijn dat de zorglast in de 'verpleeghuizen nieuwe stijl' dan ook fors zal toenemen en daarmee samenhangend het vereiste integrale professionele zorgniveau.

Natuurlijk zal er in de nieuwe verpleeghuizen veel meer aandacht zijn voor de privacy van patiënten en ook voor een leef- en zorgomgeving die goed bij de doelgroepen past.

De 'verpleeghuizen nieuwe stijl' zullen verder als thuisbasis voor de professionals functioneren en zich ook op vele plaatsen ontwikkelen tot kenniscentra, waarin aan een breed scala aan onderwijs- en onderzoeksactiviteiten geparticipeerd zal worden.

De verpleeghuisprofessionals (w.o. de verpleeghuisarts) zullen in en vanuit deze 'verpleeghuizen nieuwe stijl' werkzaam kunnen zijn in allerlei rollen (consulent, medebehandelaar, hoofdbehandelaar etc.) én in ons totale gezondheidszorgsysteem (eerstelijn, tweedelijn, derde lijn). 
Ze zullen dit ook doen vanuit een zekere trots in plaats van afkeer van hun thuisbasis en zinloze discussies over een andere naamgeving van het vakgebied verpleeghuisgeneeskunde zijn dan niet meer nodig. Verpleeghuisgeneeskunde, in het Engels nursing home medicine, heeft dus een goede toekomst voor zich!

\section{Op weg naar integrated care?}

Een relevante vraag blijft in hoeverre men in de nu nog veelal gefragmenteerde ouderenzorg zelf daadwerkelijk kan komen tot een echte integrale zorgverlening met de juiste afstemming tussen verschillende zorgaanbieders en zorgprofessionals onderling.

Geïntegreerde zorg (d.i. het concept van de "integrated care") betekent in feite het bieden van een coherent en gecoördineerd zorgaanbod, dat tot stand komt via een reeks van organisaties (zorg/welzijn) respectievelijk samenwerkende zorgprofessionals en informele zorgers én dat in feite het hele veld van de gezondheidszorg en de sociale ondersteuning kan bestrijken. De finale doelstelling is om zorgvragers op het juiste moment en op de gewenste plaats vraaggestuurde zorgen dienstverlening te verschaffen.

In de Engelstalige literatuur spreekt men niet alleen van het reeds genoemde "integrated care", maar ook wel van "integral care", "shared care", "continuing care", "transmural care" en "comprehensive care".29,30 In Nederland zijn de laatste jaren, als alternatieve omschrijvingen van het fenomeen geïntegreerde zorg, termen als "transmurale zorg", "netwerkzorg" en "ketenzorg" in zwang gekomen.

In allerlei verschijningsvormen zijn er in ons land het afgelopen decennium transmurale projecten ontwikkeld en geïmplementeerd. Doelgroepen voor geïntegreerde zorg zijn daarbij veelal chronisch zieken, w.o. fragiele ouderen. Gerelateerd aan ziekten, focust de integrale ketenzorg zich op doelgroepen zoals patiënten met diabetes mellitus, chronisch orgaanfalen, w.o. chronisch longlijden (COPD), status na CVA en dementie.

Diverse zorg- en dienstverleners kunnen betrokken zijn, zoals (medewerkers van) ziekenhuizen, verpleeghuizen, verzorgingshuizen, thuiszorgorganisaties, welzijnsorganisaties; verder huisartsen, vrijwilligersorganisaties, mantelzorgers en organisaties voor mantelzorgondersteuning en niet te vergeten ook de zorgverzekeraars. De opzet en organisatie laat een kleurrijk palet zien.

Een interessante ontwikkeling van de laatste jaren, die in dit verband niet onvermeld mag blijven en in de toekomst zeker gevolgd moet worden, is 
de toenemende transmurale inzet van verpleegkundigen. Deze worden steeds vaker de schakels tussen verschillende zorgverleners onderling en tussen zorgverleners en betrokken patiënten. Ze kunnen optreden als intermediërende zorgconsulenten en als casemanagers en spelen niet zelden een centrale rol in de communicatie. Bovendien nemen ze in de chronische zorg, in relatie tot de medische as, ook meer en meer bepaalde medische taken op zich.

Hoe dan ook, geconstateerd mag worden dat men uiteindelijk pas aan het begin staat en dat, ondanks het breed onderkende belang van samenwerking, de structurele borging van geïntegreerde zorg- en dienstverlening in ons land nog niet heeft plaatsgevonden. ${ }^{29}$

Het ontwikkelen van geïntegreerde zorg- en dienstverlening is immers geen sinecure in een land waarin zoveel verschillende zorgaanbieders en disciplines nog steeds verdeeld zijn over onderscheiden echelons en ieder hun eigen autonomie, organisatiewijze en verschillende belangen kennen. En dat is nog niet alles. De verschillende spelers kennen vaak elkaars functie en werkwijze nauwelijks, ze hebben niet zelden weinig vertrouwen in samenwerking en vertonen veelal ook een primaire grondhouding van weerstand tegen verandering.

Dit houdt in feite een situatie in stand zoals in 2006 beschreven door Keizer in Medisch Contact, waarin hij vermeldt dat alle betrokkenen in de zorg weliswaar hun best doen, maar er samen een 'klerezooi' van maken....... ${ }^{31}$

Verder draagt de bureaucratische context van de ingewikkelde regelgeving en financiering ook niet echt bij aan een flexibele en creatieve houding.

Westendorp noemde derhalve, eveneens in 2006, het huidige Nederlandse gezondheidszorgsysteem niet voor niets insufficiënt voor oude mensen. ${ }^{32}$

De huidige situatie op dit gebied is dus nog te kenschetsen als structureel onevenwichtig.

Vooralsnog veroorzaakt dit moeilijkheden met betrekking tot het continueren en verspreiden van goede transmurale initiatieven en is de progressie die gemaakt wordt in het algemeen nog te gering. Dat geldt zowel voor de interorganisationele samenwerking als voor de samenwerking tussen onderscheiden professionals (bijv. in de medische of verpleegkundige as). ${ }^{29-33}$

Verdere facilitering van transmurale samenwerking zal o.a. moeten geschieden door flexibilisering van de wet- en regelgeving en vereenvoudiging van de financiering. Bovendien zal het ook een duidelijke attitudeverandering en samenwerkingsvaardigheden van 
alle betrokken partijen en professionals vereisen; iets waaraan in de beroepsopleidingen veel meer gewerkt zou moeten worden.

Tenslotte zou er ruimte moeten komen om nog meer zorgvernieuwend, maar wel resultaatgericht te experimenteren, met parallel daaraan lopend goede wetenschappelijke evaluaties, gericht op effectiviteit, doelmatigheid en niet te vergeten het cliëntenperspectief.

Op weg dus naar een value based integrale ouderenzorg en ouderengeneeskunde.

\section{De verpleeghuisgeneeskunde in de toekomst; onderdeel van een dynamisch netwerk van medische zorg voor ouderen}

Zoals genoemd, functioneren ook de medische disciplines voor ouderen in ons land nog teveel los van elkaar. Organisatorisch heeft de focus altijd gelegen op de afbakening van het territorium van elk vakgebied en in de uitvoering is veelal slechts sprake geweest van verwijscontacten. Een betere afstemming en samenwerking tussen de in ons land beschikbare modaliteiten, te weten de generalistische en specialistische medische zorg voor ouderen is dus dringend nodig, simpelweg om tegemoet te komen aan een betere en duurzame continuïteit van de preventieve, curatieve en care-georiënteerde medische zorg voor kwetsbare ouderen en ouderen die reeds geriatrische patiënt zijn geworden. Het complexe profiel van de kwetsbare of fragiele oudere en ook dat van de geriatrische patiënt vragen daar, in het verlengde van de eerder beschreven mankementen van onze huidige ouderenonvriendelijke gezondheidszorg, nadrukkelijk om.

Figuur 1 illustreert dit op mooie wijze. Determinanten in de levensloop bepalen het verloop van het verouderingsproces van de mens en ook of deze gedurende het leven getroffen wordt door ziekte. Aspecten van veroudering en ziekte kunnen op hun beurt weer aanleiding geven tot een toestand van fragiliteit (in het Engels 'frailty'), een verhoogde kwetsbaarheid dus, die zich kan uiten op somatisch, psychisch en sociaal gebied. Een toestand van progressieve kwetsbaarheid kan tenslotte leiden tot ongewenste uitkomsten zoals multimorbiditeit en handicaps en daarmee samenhangende gezondheidszorgconsumptie; het typische profiel van de geriatrische patiënt dus. Direct onder de tijdslijn van het leven staan ook de interventiemogelijkheden vermeld. 


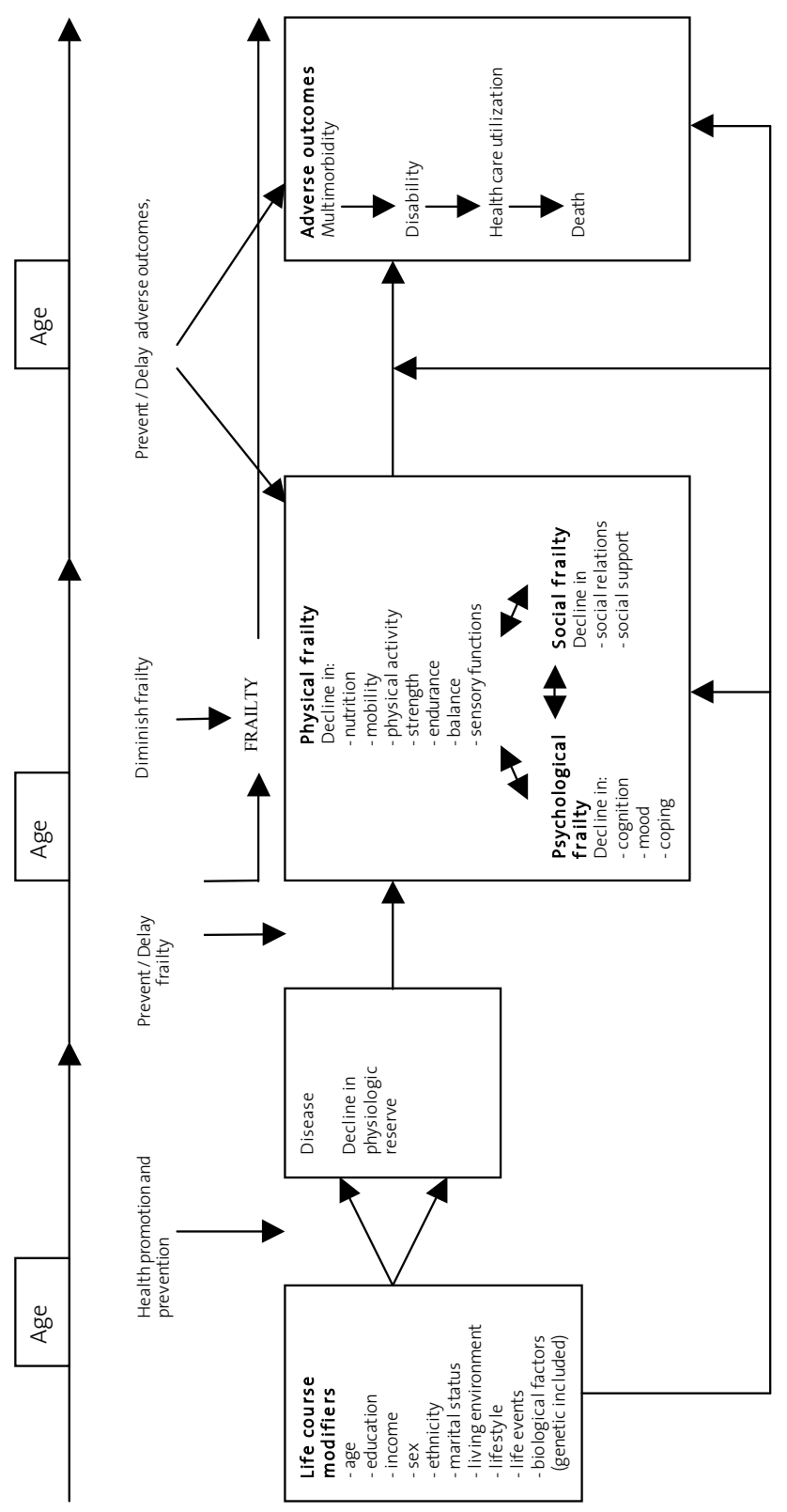

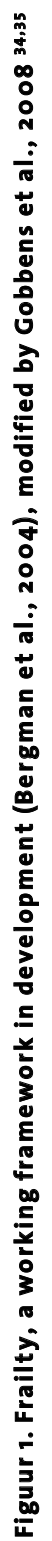


Begin 2008 kwam het rapport 'Ouderdom komt met gebreken; geneeskunde en zorg bij ouderen met multimorbiditeit van de Gezondheidsraad (GR)' uit, waaraan ik ook een bijdrage heb mogen leveren.36

In dit rapport worden, ik citeer ..."de beroepsbeoefenaren binnen een bepaalde regio (w.o. huisartsen, verpleeghuisartsen, klinisch geriaters, internisten ouderenzorg, ouderenpsychiaters) én de organisaties (ziekenhuizen, apothekers, thuiszorgorganisaties, verpleeghuizen en verzorgingshuizen, GGZ-afd. ouderenzorg) opgeroepen om samen met elkaar en met de verzekeraars tot regionale afspraken te komen over de inhoud en organisatie van zorgtrajecten voor ouderen met complexe problematiek".

In feite stelt het rapport dat er 5 grote opgaven liggen t.b.v. ouderen met multimorbiditeit:

1. de tijdige signalering van de gezondheidsrisico's van multimorbiditeit;

2. de regie over de zorg aan de individuele patiënt met multimorbiditeit in de eerstelijn moet goed geregeld zijn, waarbij een belangrijke rol aan de huisarts wordt toegeschreven;

3. er moet veel meer ruimte komen voor specialistisch advies en ondersteuning van de eerstelijn (lees met name huisarts, maar ook thuiszorg) door de tweede (ZH) en derde lijn (VH en GGZ);

4. de toepassing van specifieke kennis moet plaatsvinden in de kliniek of in andere moderne "(klinische) intramurale omgevingen" (herstelkliniek, hospice, verpleeghuis nieuwe stijl, specifieke afdelingen binnen de GGZ etc.);

5. het realiseren van betere onderlinge afstemming en samenwerking is dringend gewenst.

Het adequaat tegemoet komen aan deze opgaven is voorwaar een uitdaging voor alle in het voorgaande genoemde organisaties en professionals en misschien wel een extra grote uitdaging voor de verpleeghuisgeneeskunde en de verpleeghuisarts in het bijzonder.

De verpleeghuisarts zal nog veel meer dan voorheen actief moeten werken buiten de muren van het verpleeghuis, want tot nu toe wordt er nog veel te weinig gebruik gemaakt van de mogelijkheden die de verpleeghuisgeneeskunde kan bieden aan ouderen en chronisch zieken die zich buiten het verpleeghuis bevinden.

De al meer dan 15 jaar bestaande consultatiefunctie van de 
verpleeghuisarts alsmede de verpleeghuisgeneeskundige inbreng in de aanvullende zorg in het verzorgingshuis en thuis, hebben er jammer genoeg nog niet toe geleid dat de verpleeghuisgeneeskunde een transparante, complementaire, herkenbare en gekende plaats in de extramurale zorg heeft ingenomen. 4,37,38

Diverse redenen zijn daarvoor aan te voeren waaronder aspecten van marktwerking en concurrentie, het feit dat andere professionals, waaronder huisartsen en specialisten nog steeds onvoldoende op de hoogte zijn van wat de verpleeghuisgeneeskunde eigenlijk inhoudt en hetgeen de verpleeghuisarts überhaupt kan bieden én voorts de onduidelijke regelgeving en financiering.

Daarbij heeft de verpleeghuisgeneeskunde zelf ook een onvoldoende gezonde drang tot profilering getoond en waren en zijn verpleeghuisartsen veelal niet blij met de wijze waarop ze mogen acteren buiten de muren van het verpleeghuis; met name vanwege de gebrekkige bevoegdheden die ze extramuraal hebben.

Niet overal is het slecht gegaan en daar waar de samenwerking tussen verpleeghuisartsen en huisartsen en ook tussen verpleeghuisartsen en medisch specialisten wel meer gestalte heeft gekregen, hangt dit samen met voor de hand liggende elementaire samenwerkingsprincipes, waaronder het maken van relevante samenwerkingsafspraken, het zorgen voor gezamenlijke betrokkenheid bij de zorg (dus simpelweg het samen naar patiënten kijken) en tenslotte ook door het maken van afspraken met zorgverzekeraars over financiële ondersteuning van bewezen zinvolle samenwerking.4,39

Duidelijk is dat er zeker kansen zijn en de complementaire waarde van de verpleeghuisgeneeskunde is de laatste jaren bovendien vaker beschreven, ook mede vanuit onze groep alhier. $4,38,39$

Refererend aan figuur 1 kan de verpleeghuisarts m.i. een rol spelen voor fragiele ouderen enerzijds en geriatrische patiënten en chronisch zieken anderzijds.

Primaire preventie van fragiliteit (frailty) bij ouderen lijkt me op voorhand meer een taak van de public health sector en de eerstelijn, waarbij ik met name denk aan de GGD en de huisartsenzorg.

Preventie van verergering van reeds ontstane fragiliteit, met empowering van de kwetsbare oudere of chronisch zieke, die nog in de eigen woonomgeving verblijft, kan wel mede een taak van de verpleeghuisarts worden, omdat deze bij uitstek goed op de hoogte is van beïnvloedbare factoren die normaliter snel tot institutionalisering kunnen leiden. 
Ook kan de verpleeghuisarts een rol spelen t.b.v. het integrale herstel van oudere patiënten die bijvoorbeeld tijdelijk minder functioneren als gevolg van een ziekenhuisopname voor een operatieve ingreep (heup OK) of na een decompensatiefase van een aanwezig orgaanfalen; of zelfs na een delier.

Uiteraard is de verpleeghuisgeneeskundige expertise inzetbaar voor zieke ouderen, die moeten herstellen en revalideren na een aandoening die tot blijvende schade heeft geleid ( m.n. CVA).

En natuurlijk blijft de verpleeghuisarts de integrale, generalistische dokter bij uitstek voor geriatrische patiënten en chronisch zieken die 24 uur per dag op verpleeghuiszorg zijn aangewezen; tegenwoordig noemen we dat "permanent wonen met zorg en behandeling". Bij deze laatste groep zal de verpleeghuisarts bij de totale zorg en behandeling, als regisseur van het multidisciplinaire zorgteam, de kwaliteit van leven steeds laten prevaleren, vanaf het moment van definitieve opname tot aan de dood.

Op een andere manier geduid en meer specifiek gekoppeld aan ons gezondheidszorgbestel kan de verpleeghuisarts in de toekomst een nog meer herkenbare rol spelen in de netwerkzorg voor zieke en zorgbehoevende ouderen; een rol die in het ziekenhuis, de eerstelijnszorg en het verpleeghuis duidelijk gestalte kan krijgen.

1. Ten aanzien van het ziekenhuis is nog op veel meer plaatsen in ons land een zinvolle additionele en complementaire inzet van de verpleeghuisarts nieuwe stijl in het ziekenhuis mogelijk bij:

- poliklinische, multidisciplinaire ziekte- en zorgdiagnostische activiteiten t.b.v. ouderen met cognitieve problemen (ik bedoel de dementiediagnostiek in de ruimste zin van het woord); te denken valt bijvoorbeeld aan de inbreng in een zogenaamd DOC-PG a of GOAC in het ziekenhuis;

poliklinische, multidisciplinaire ziekte- en zorgdiagnostische activiteiten t.b.v. ouderen met failure to thrive, d.w.z. fragiele ouderen die door een toename van de complexiteit van hun somatische ziekte- en zorgproblematiek, thuis dreigen vast te lopen; te denken valt bijvoorbeeld aan de inbreng in een zogenaamd DOC-SOM ${ }^{b}$ of GOAC ${ }^{c}$ in het ziekenhuis;

- $\quad$ het monitoren en behandelen van uitbehandelde ouderen, die in het ziekenhuis verspreid een verkeerd bed bezetten of op transferafdelingen liggen. 
a Het DOC-PG (Diagnostisch OnderzoeksCentrum voor PsychoGeriatrische patiënten) is een regionaal adviescentrum ten behoeve van de huisartspraktijk. Het voorziet in een multidisciplinaire beoordeling van oudere patiënten die worden verdacht van het hebben van een complexe combinatie van somatische en psychogeriatrische aandoeningen. Deze beoordeling bestaat uit een somatische en psychogeriatrische beoordeling en het inschatten van de benodigde zorg. Beoordeling vindt plaats binnen twee weken na aanmelding en bestaat uit een huisbezoek vanuit de RIAGG ouderenzorg en twee dagdelen onderzoek in het ziekenhuis. Het onderzoek mondt uit in een (multi-axiale) diagnose en een behandelplan, geformuleerd in een wekelijkse multidisciplinaire bijeenkomst en op schrift gesteld voor de verwijzende huisarts. ${ }^{39}$

b Het DOC-S (Diagnostisch OnderzoeksCentrum voor Somatische patiënten) is in feite een naar het model van het DOC-PG functionerend regionaal adviescentrum ten behoeve van de huisartspraktijk. Het voorziet in een multidisciplinaire beoordeling van oudere patiënten die worden verdacht van het hebben van een complexe combinatie van somatische aandoeningen. Deze beoordeling bestaat uit een somatische en (zo nodig) psychogeriatrische beoordeling en het inschatten van de benodigde zorg. Beoordeling vindt plaats binnen twee weken na aanmelding en bestaat uit een huisbezoek vanuit de afdeling Interne-ouderengeneeskunde en één tot twee dagdelen onderzoek in het ziekenhuis. Het onderzoek mondt uit in een of meer diagnoses en een behandelplan, geformuleerd in een wekelijkse multidisciplinaire bijeenkomst en op schrift gesteld voor de verwijzende huisarts.

c Een GOAC (Geriatrisch Onderzoek en Adviescentrum) combineert als het ware de DOC-PG en DOC-S benadering, waarbij het nu een samenwerking betreft tussen een ziekenhuis (w.o. geriatrie, neurologie en psychiatrie (de laatste evt. vanuit de GGZ) en een verpleeghuis. Het functioneert als een regionaal adviescentrum ten behoeve van de huisartspraktijk. Het voorziet in een multidisciplinaire beoordeling van oudere patiënten die worden verdacht van het hebben van een complexe combinatie van somatische e/o psychogeriatrische aandoeningen. Deze beoordeling bestaat uit een somatische e/o psychogeriatrische beoordeling en het inschatten van de benodigde zorg. Beoordeling vindt plaats binnen een afgesproken korte periode na aanmelding en bestaat uit een huisbezoek vanuit het verpleeghuis en een dagdeel onderzoek in het ziekenhuis. Het onderzoek mondt uit in een of meer diagnoses en een behandelplan, geformuleerd in een wekelijkse multidisciplinaire bijeenkomst en op schrift gesteld voor de verwijzende huisarts. ${ }^{40}$ 
De rol van de verpleeghuisarts kan daarbij variëren van consulent tot medebehandelaar, waarbij uiteraard goede afstemmings- en samenwerkingsafspraken met andere medisch specialisten nodig zijn en ook met de huisarts, daar waar de diagnostische activiteiten bijvoorbeeld gericht zijn op het op verantwoorde wijze thuis houden van zieke en zorgbehoevende ouderen.

Her en der ontwikkelen zich in ons land, zoals gememoreerd, op dit moment ook steeds meer en specifieke activiteiten op het gebied van de multidisciplinaire herstelzorg voor ouderen na een voorgaande ziekenhuisopname of in vervolg op een decompensatie in de thuissituatie. De toenemende ziekenhuisverplaatste zorg draagt daaraan bij. Op sommige plaatsen worden zelfs plannen uitgewerkt voor specifieke herstelzorgklinieken, zoals de herstelkliniek die over enige tijd in Maastricht, als initiatief van Vivre, Stichting Clara Fey en het Academische Ziekenhuis Maastricht gebouwd zal worden. In deze kliniek zal de oorspronkelijke revalidatiezorg van het verpleeghuis voor voornamelijk CVA-patiënten en post heup-OK patiënten aangevuld worden met herstelzorg voor ouderen na ziekenhuisopname op bijvoorbeeld de afdeling interne geneeskunde of na pluriforme chirurgische ingrepen én voor ouderen met uitbehandeld orgaanfalen, die moeten herstellen na een intercurrente decompensatie Het zal duidelijk zijn dat verpleeghuisartsen zich hiertoe zeker nader moeten verdiepen in de gerontorevalidatie en t.a.v. een aantal specifieke medische vakgebieden (w.o. de cardiologie en pulmonologie).

Verder behoeft in de herstelzorg ook de ketengedachte nadere uitwerking omdat deze patiënten veelal weer terugkeren naar de thuissituatie en er dus voor een goede transitie naar en afstemming met de eerstelijn (huisarts en thuiszorg) zorg gedragen moet worden.

2. Ten aanzien van de eerstelijn en de huisarts in het bijzonder kan en moet de verpleeghuisarts nieuwe stijl ook veel sterker zijn toegevoegde waarde, in diverse rollen, inbrengen.

Die toegevoegde waarde houdt veel meer in dan slechts het aanschuren tegen de huisartsgeneeskunde zoals dat veelal de afgelopen 10-15 jaar is gebeurd in met name de verzorgingshuizen. 
De verpleeghuisarts kan door de huisarts bijvoorbeeld:

- als consulent ingeschakeld worden om de complexe problematiek van zieke en zorgbehoevende ouderen thuis en in het verzorgingshuis (of woonzorgcentrum nieuwe stijl) in kaart te brengen én te adviseren t.a.v. interventies die kunnen bijdragen om de oudere ter plekke te kunnen laten blijven wonen en de mantelzorg voelbaar te ondersteunen;

- als deelbehandelaar ingeschakeld worden bij specifieke zorgproblemen thuis of in het woonzorgcentrum, zoals decubitus, incontinentie, vallen en probleemgedrag.

- eventueel gevraagd worden om de behandelverantwoordelijkheid voor bepaalde hulpbehoevende ouderen thuis of in het woonzorgcentrum (tijdelijk) over te nemen.

In de ketenzorg voor dementie die ook op steeds meer plaatsen gestalte krijgt, kan de verpleeghuisarts, op basis van zijn kennis en expertise m.b.t. intercurrente medische en zorg problemen, gedurende het verloop van dementie, vanuit het verpleeghuis of de GGZ-afdeling ouderen, in de eerstelijn een rol spelen als consulent of medebehandelaar bij:

- de diagnostiek thuis of in het woonzorgcentrum;

- de behandeling ( bijvoorbeeld het mede monitoren van een behandeling met cholinesteraseremmers en psychofarmaca); en

- de begeleiding van de dementerende en diens mantelzorgers (bv. bepalen van de draagkracht van de mantelzorg, bepalen van de noodzaak voor respijtzorg of van definitieve verpleeghuisopname etc.).

Het is daarbij absoluut niet ondenkbaar dat de verpleeghuisarts af en toe daadwerkelijk op dagdelen als consulent of medebehandelaar werkzaam is in de huisartspraktijk zelf.

Een vergelijkbaar plaatje is te maken voor de eveneens ketengeoriënteerde palliatieve zorg, waarbij de, hiertoe overigens bij voorkeur specifiek (bij) geschoolde, verpleeghuisarts thuis en in woonzorgcentra een rol kan spelen bij de diagnostiek en behandeling van moeilijke symptomatologie in de palliatieve fase, inclusief de toepassing van palliatieve sedatie; en voorts ook bij de begeleiding van de patiënt en diens verwanten.

3. Tenslotte zal de verpleeghuisarts als hoofdbehandelaar werkzaam blijven in het verpleeghuis nieuwe stijl en daarvan afgeleide 
woonvormen voor ouderen en chronisch zieken die voor 24 uur op chronische zorg zijn aangewezen.

In het verpleeghuis zal de verpleeghuisarts bovendien, als intramurale netwerker, nog meer dan vroeger moeten werken aan de verdieping van de verpleeghuisgeneeskunde en zal ook extra aandacht moeten uitgaan naar een nieuwe impuls voor de intramurale samenwerking tussen verpleeghuisarts en verpleegkundigen, waarvan er de laatste jaren zoveel uit de instellingen verdwenen zijn. ${ }^{22}$

Het zal de verpleeghuisgeneeskunde een dringend noodzakelijke kwaliteitsimpuls geven, want de kritiek die vaak op de kwaliteit van de verpleeghuiszorg geuit wordt, moet de verpleeghuisgeneeskunde zich immers ook zelf aantrekken. ${ }^{41}$

Derhalve ben ik ook een vurig pleitbezorger voor het formuleren van transparante kwaliteitscriteria voor de verpleeghuisgeneeskundige zorg, het op rasse schreden verder gaan met de ontwikkeling en implementatie van nog veel meer value based beroepsspecifieke richtlijnen en ook met een veel grootschaliger betrokkenheid van verpleeghuizen en verpleeghuisartsen bij verpleeghuisgeneeskundig wetenschappelijk onderzoek respectievelijk zorgonderzoek.3,4,16,21,42 Verder zal de verpleeghuisarts ook in het verpleeghuis zelf nog veel nadrukkelijker moeten samenwerken met allerlei andere specialisten en in het bijzonder met de huisarts, de klinisch geriater of, waar aanwezig, de internist ouderen en de ouderenpsychiater. Zij kunnen in het verpleeghuis immers ook als consulent en medebehandelaar optreden; en waarom ook niet?! Overal is immers medische netwerkzorg uit te voeren, ook in het verpleeghuis én op sommige plaatsen gebeurt dit al.

De brede en complementaire inbreng van de verpleeghuisgeneeskunde in relatie tot andere medische disciplines t.b.v. ouderen, staat of valt uiteindelijk met het maken van goede afspraken over onderscheiden taken, verantwoordelijkheden en rollen, zodat ieders toegevoegde waarde transparant aanwezig en erkend is.

Het staat of valt ook bij het feit of werkers in de gezondheidszorg, waaronder artsen van verschillende achtergrond, in staat zijn om hun rol te relativeren en te beschouwen als ondersteuning en niet als overname van verantwoordelijkheden van en voor de ander, niet in de laatste plaats ook de patiënt zelf.43

De regievraag is dan alleen nog maar daar van belang, waar deze 
ertoe leidt dat een hoger niveau van relevantie van de samengestelde zorgverlening bereikt wordt in vergelijking tot de inbreng van de afzonderlijke werkers in de zorg afzonderlijk. 44

En in deze sluit ik me ook graag aan bij de conclusies die in het genoemde GR rapport gemaakt worden.

Het belang van netwerkachtige ouderenzorg en ouderengeneeskunde moet natuurlijk eveneens uitgedragen worden door de onderscheiden beroepsorganisaties, die er ook tools voor moeten ontwikkelen; denk bijvoorbeeld aan de LESA 's (Landelijke Eerstelijns Samenwerkings Afspraken) én samenwerken moet bovendien geleerd worden in de basisopleidingen, de vervolgopleidingen en via relevante nascholingsactiviteiten. 4,45,46

Tenslotte moet er natuurlijk in de nabije toekomst ook een financiering komen die integrale zorgverlening daadwerkelijk en passend financiert; denk bijvoorbeeld aan de ontwikkeling van transmurale samengestelde DBC's. 43

Ook dat laatste is een uitdaging, maar geen onoverkomelijke, want de ouderenzorg zal echt niet alleen maar duurder worden! 47

\section{Nationaal Programma Ouderenzorg 2008}

Het recent gestarte Nationaal Programma Ouderenzorg (NPO) van ZONMW zal hopelijk zichtbaar bijdragen aan het realiseren van de opgaven, zoals beschreven in het gerefereerde GR rapport. ${ }^{48}$

De ontwikkeling van een innovatieve en 'value based' integrale ouderenzorg zal gestalte moeten krijgen via de uitvoering en evaluatie van een veelkleurig palet aan samenwerkingsexperimenten (met aandacht voor onder meer innovatieve zorgorganisatie, zorglogistiek, samenwerking en financiering) om zo de voorgestane netwerkzorg voor kwetsbare en hulpbehoevende ouderen daadwerkelijk te realiseren.

Daarbij horen ook experimenten waarin de genoemde pluriforme rol van de verpleeghuisarts tot uiting komt in relatie tot de eerstelijn en het ziekenhuis.

In en vanuit het Maastrichts Universitair Medisch Centrum+ zal hieraan gestalte gegeven worden vanuit het recent opgerichte Academisch Centrum ZorgInnovatie Ouderen (ACZIO).49 


\section{Wat verwacht ik van de persoonlijke opstelling van de verpleeghuisarts nieuwe stijl?}

De verpleeghuisarts nieuwe stijl zal bij dit alles een pro-actieve rol moeten aannemen en actief moeten meedoen in de regio.

Intramuraal moet de verpleeghuisarts er voor gaan om het eigen vakgebied op een kwalitatief zo hoog mogelijk niveau te brengen en eraan meewerken dat de totale expertise van het verpleeghuis in de regio kan uitstralen. ${ }^{50}$

Extramuraal zal de verpleeghuisarts actief de boer op moeten om het vakgebied breed uit te dragen en, let wel, de complementaire meerwaarde ervan zichtbaar te maken aan alle relevante spelers in de ouderenzorg, inclusief de kwetsbare en hulpbehoevende ouderen zelf. Ik wens de verpleeghuisartsen daarbij de bezieling van een missionaris toe en de overtuigingskracht van een tweedehands autohandelaar, want het realiseren van een pluriforme verpleeghuisgeneeskundige inbreng in onze ouderenzorg zal niet van de ene op de andere dag geschieden. In dit verband verwijs ik graag naar een uitspraak van de Belgische schrijver Stefan Brijs: "changing happens person by person" en dan snapt $U$ meteen ook de twee bijzondere kwaliteiten die ik de verpleeghuisarts zojuist toewenste.

Ik droom mij in ieder geval verpleeghuisartsen die met passie deze uitdagingen aangaan. 


\section{Verpleeghuisgeneeskunde aan de UM}

De bijzondere en op termijn gewone leerstoel Verpleeghuisgeneeskunde is per 1 mei 2007 aan de UM ingesteld.

In haar nog relatief korte periode van bestaan heeft het vakgebied reeds een plaats verworven binnen het Maastrichtse universitaire onderwijs en onderzoek.

\section{Verpleeghuisgeneeskundig onderwijs aan en vanuit de Faculty of Health, Medicine and Life Sciences (FHML); UM}

Het belang van goed universitair geneeskundig onderwijs in de ouderengeneeskunde wordt internationaal en nationaal gelukkig meer en meer onderkend.

Internationaal zijn vanuit de WHO en de International Association of Gerontology and Geriatrics zelfs basic contents (zie tabel 1) for undergraduate medical training beschreven, mede vanuit de visie die stelt dat "...throughout the 21th century, health professionals will increasingly be required to be familiair with old age care whatever the specialty they choose"...51

Nationaal past dit in het groeiende bewustzijn betreffende een goede zorg voor kwetsbare en hulpbehoevende ouderen, dat in het voorgaande genoeg uitgelegd is. 


\section{Tabel 1. World Health Organization and International Association of Gerontology and Geriatrics}

Geriatric Medicine: basic contents for Undergraduate Medical Teaching

\begin{tabular}{|c|c|}
\hline 1. & $\begin{array}{l}\text { Understand the biology of ageing and its relationship to the clinical manifestations of } \\
\text { diseases in older individuals. Older patients manifest signs and symptoms of disease } \\
\text { because they are sick, not because they are old. }\end{array}$ \\
\hline 2. & $\begin{array}{l}\text { Demonstrate appropriate knowledge of physiology of ageing to understand concepts } \\
\text { such as frailty and loss of functional capacity. }\end{array}$ \\
\hline 3. & Demonstrate knowledge of the demography of ageing. \\
\hline 4. & $\begin{array}{l}\text { Demonstrate sufficient knowledge of pharmacology in order to understand basic } \\
\text { principles of prescribing for older people, with special attention to adverse effects and } \\
\text { iatrogenic disease. This includes not only knowing what to prescribe but also when drugs } \\
\text { should be withdrawn, and the risks of polypharmacy. }\end{array}$ \\
\hline 5. & $\begin{array}{l}\text { Recognize the role of psychosocial risk factors, such as living alone, economic hardship } \\
\text { and lack of social support, in the causation and experience of disease. }\end{array}$ \\
\hline 6. & $\begin{array}{l}\text { Recognize the importance of providing support to family caregivers who, themselves, may } \\
\text { be old and in poor health. }\end{array}$ \\
\hline 7. & Recognize prevention and rehabilitation as the main goals of Geriatric Medicine. \\
\hline 8. & $\begin{array}{l}\text { Understand that the optimisation of health in frail older people or those with disabilities } \\
\text { requires multi-dimensional evaluation and multidisciplinary approaches for the } \\
\text { attainment of better outcomes. }\end{array}$ \\
\hline 9. & $\begin{array}{l}\text { Consider a problem-oriented approach as the most appropriate in the care of older } \\
\text { people. }\end{array}$ \\
\hline 10. & $\begin{array}{l}\text { Embrace a holistic perspective, understanding that older persons have a rich history } \\
\text { behind them and embrace life-course events as the root of many of their current ill-health } \\
\text { conditions. }\end{array}$ \\
\hline 11. & $\begin{array}{l}\text { Understand that a life course perspective also implies that today's children and younger } \\
\text { adults are tomorrow's older people and that their health in older age depends on how } \\
\text { they live. }\end{array}$ \\
\hline 12. & $\begin{array}{l}\text { Be familiar with the management of the great geriatric syndromes - such as falls, } \\
\text { incontinence and cognitive impairment - as well as with conditions highly prevalent such } \\
\text { as depression and the subtle presentation of disease in old patients. }\end{array}$ \\
\hline 13. & Demonstrate positive attitudes to ageing, speaking out against negative stereotypes. \\
\hline 14. & Recognize the distinct aspects of abuse against older person. \\
\hline 15. & Recognize ethical issues including end of life care. \\
\hline
\end{tabular}

De activiteiten op het gebied van het verpleeghuisgeneeskundig onderwijs zijn onder te verdelen in activiteiten t.b.v. het universitaire onderwijs en t.b.v. de postgraduate scholing en nascholing. 


\section{Onderwijsactiviteiten t.b.v. het basiscurriculum geneeskunde}

Het onderwijs in de geneeskunde aan de UM vindt plaats volgens het Probleem Gestuurd Onderwijs principe (PGO) in de vorm van blokonderwijs, keuzeonderwijs en praktisch medisch onderwijs.

Inmiddels is men al weer enige tijd geleden gestart met een Nieuw Maastricht Curriculum. Dit curriculum is gericht op sturing van eigen verantwoordelijkheid en zelfstandigheid voor het eigen leren. Het is nog meer praktijk- en patiëntgebonden, besteedt meer aandacht aan wetenschappelijke vorming en kent als belangrijkste kerndoelstelling een betere integratie van het praktisch medisch onderwijs en het theoretisch onderwijs.

Op dit moment worden vanuit de verpleeghuisgeneeskunde structurele onderwijsactiviteiten ten behoeve van studenten geneeskunde (nieuwe curriculum) vervuld in het tweede en zesde studiejaar.

Incidenteel wordt ook nog service verleend aan studenten in het oude curriculum, welke in het vierde studiejaar of daarna een periode keuzeonderwijs willen volgen.

Collega verpleeghuisarts Rachele Arends van Vivre vervult daarbij vanuit de Vakgroep Huisartsgeneeskunde op enthousiaste wijze de rol van coördinator verpleeghuisgeneeskundig onderwijs.

\section{De onderwijsactiviteiten specifiek (nieuwe curriculum):}

1. Sinds 2007 is er structurele betrokkenheid bij het reguliere tweedejaars onderwijsblok 2.5 met de passende titel Ageing, door participatie binnen de planningsgroep en het vervullen van lezingen en 2 tutorschappen door verpleeghuisartsen.

2. Reeds een drietal jaren is er primaire betrokkenheid bij de organisatie van het succesvolle en steeds volgetekende tweedejaars keuzeblok 2.6 "oriëntatie in de verpleeghuiszorg / verpleeghuisgeneeskunde"; in feite een 6-weekse zorgstage in het verpleeghuis.

Bij de uitvoering zijn inmiddels de verpleeghuislocaties van Vivre (Maastricht e.o.), MeanderGroep (Kerkrade e.o.), Orbis Medisch en Zorgconcern (Geleen/Sittard e.o.) en van Sevagram (Heerlen e.o.) betrokken en vanaf komend studiejaar ook de locaties van Cicero Zorggroep (Brunssum e.o.), Proteion (Horn e.o.) en Stichting Land van Horne (Weert e.o.). 
Overigens zou een korte zorgstage in het verpleeghuis eigenlijk verplicht moeten zijn voor alle studenten geneeskunde en hier ligt dus nog een opdracht voor de toekomst.

3. Sinds eind 2006 worden in het zesde studiejaar GEZP- respectievelijk WESP-stages verpleeghuisgeneeskunde van elk 18 weken aangeboden voor semi-artsen, aanvankelijk alleen binnen de locaties van Vivre in Maastricht, maar nu ook in andere Limburgse verpleeghuizen. Het betreft participatiestages in de praktijk van de gezondheidszorg (GEZP) en wetenschapsstages (WESP). 52

De Participatiestage in de Gezondheidszorg (GEZP stage) biedt de semi-arts de mogelijkheid om ervaring en verdieping op te doen in het door de student gekozen vakgebied, in dit geval dus de verpleeghuisgeneeskunde. Als semi-arts mag de student tijdens de GEZP-verpleeghuisgeneeskunde in grote mate zelfstandig functioneren in het verpleeghuis. Destudent begeleidt eigen patiënten (zowel intramuraal als semimuraal), voert zelfstandig gesprekken met patiënten en familie en doet voorstellen t.a.v. diagnostiek en behandeling. ${ }^{22}$ De GEZP-verpleeghuisgeneeskunde kan daarbij zeker bijdragen aan de wenselijke instroom van basisartsen in de specialisatie-opleiding tot verpleeghuisarts

Inmiddels is dit jaar reeds 1 student na afstuderen ingestroomd in de vervolgopleiding tot verpleeghuisarts en volgt komend jaar de tweede. Zoals al eerder aangegeven 'changing, of misschien beter, choosing from conviction, after concrete experience, happens person by person'!

Een WESP stage kan worden gevolgd binnen een van de onderzoeksinstituten van de Faculty of Health, Medicine and Life Sciences (FHML); verpleeghuisgeneeskunde is ondergebracht bij de onderzoekschool CAPHRI. De onderzoeksinstituten bieden deels uitgewerkte onderzoeksvoorstellen aan. Studenten mogen echter ook zelf een onderzoeksvoorstel formuleren, binnen of buiten een FHML-onderzoeksinstituut, binnen of buiten Nederland (onder voorwaarde dat de onderzoeksinstelling op de een of andere wijze verbonden is met de Universiteit Maastricht). De WESP-stage gerelateerd aan de verpleeghuisgeneeskunde / verpleeghuiszorg biedt studenten de gelegenheid zich te bekwamen in een aantal 
algemene en disciplinegebonden competenties. De student leert de grondbeginselen van wetenschappelijk onderzoek, zoals rapporteren, interpreteren, evalueren, hypothesevorming, methodiek en statistiek. $\mathrm{Na}$ literatuurstudie formuleert de student een wetenschappelijke vraagstelling; aan de hand van een onderzoeksmethode voert hij/ zij een onderzoek uit; de onderzoeksresultaten worden kritisch geanalyseerd; de eindresultaten van het onderzoek presenteert de student schriftelijk en mondeling. ${ }^{52}$

Uiteraard worden alle genoemde onderwijsactiviteiten de komende jaren op enthousiaste wijze gecontinueerd. Verdere uitbreiding behoort ook tot de mogelijkheden, doch is mede afhankelijk van de mogelijkheden binnen de personele formatie, die op dit moment helaas nog maar zeer summier is.

Bijzondere vermelding verdient nog de redactionele medewerking vanuit UM-verpleeghuis-geneeskunde aan het in september 2008 verschenen Vlaams-Nederlandse leerboek 'Probleemgeoriënteerd denken in de geriatrie', waaraan vooraanstaande specialisten op het gebied van de generalistische en specialistische ouderengeneeskunde in België en Nederland hebben meegeschreven en ook twee medisch studenten, die op mooie wijze, via een eigen geschreven essay, het belang van een leerboek geriatrie als leidraad voor de zoektocht door de geriatrische problematiek onderstrepen.53,54,55

\section{Onderwijs t.b.v. Gezondheidswetenschappen en anderen...}

Vanuit de leerstoel verpleeghuisgeneeskunde worden op onderwijsgebied incidenteel ook activiteiten verricht voor studenten gezondheidswetenschappen en psychologie.

In de praktijk krijgt dit met name gestalte in de medebegeleiding van studenten die in hun masterfase een scriptie moeten schrijven. 


\section{Postgraduate onderwijsactiviteiten:}

De postgraduate onderwijsactiviteiten betreffen specifiek de volgende:

1. De Limburgse verpleeghuizen participeren voor een groot deel aan de UM-huisartsenopleiding. In het studiejaar 2007-2008 hebben de contacten met de huisartsenopleiding ertoe geleid dat voor de eerste maal twee middagdelen onderwijs verzorgd zijn, voor respectievelijk opleidelingen tot huisarts en huisartsopleiders, tijdens een terugkomdag van Fase II van de huisartsenopleiding. Dit geschiedde in het kader van het blok Chronische Zorg en het onderwerp betrof de samenwerking tussen verpleeghuisarts en huisarts. In de nabije toekomst zullen meer onderwijsactiviteiten samen met de huisartsenopleiding georganiseerd worden.

2. De meeste Limburgse verpleeghuizen participeren ook aan de vervolgopleiding tot verpleeghuisarts in Nijmegen.

Het is vooralsnog niet aan de orde om een eigen vervolgopleiding tot verpleeghuisarts in Maastricht te beginnen. Wel is er de ambitie om, samen met de Afdeling Verpleeghuisgeneeskunde van de Radboud Universiteit Nijmegen, ook in Limburg terugkomactiviteiten voor verpleeghuisartsen in opleiding te organiseren; en eventueel ook samen met de huisartsenopleiding in Maastricht.

De duur van de vervolgopleiding tot verpleeghuisarts is met ingang van 2007 drie jaar geworden.

Vond de praktijkopleiding voorheen voornamelijk plaats in de verpleeghuizen zelf, nu komen er ook langdurige stages in o.a. ziekenhuizen, GGZ-instellingen en eerstelijn (lees huisarts-praktijk) bij.

Een en ander vergt nogal wat organisatorische aspecten om de verschillende praktijkstages in de diverse Limburgse ziekenhuizen, GGZ-instellingen etc. te regelen.

UM-verpleeghuisgeneeskunde levert m.i.v. 1-1-2008 het regiocoördinatorschap voor Zuid-Limburg t.b.v. de Vervolgopleiding tot Verpleeghuisarts (VOVA) in Nijmegen, opnieuw in de persoon van Rachele Arends. 
3. Ook op het gebied van de geaccrediteerde postgraduate nascholing is UM-verpleeghuisgeneeskunde in de afgelopen periode actief geweest.

Vanuit verpleeghuisgeneeskunde is bijvoorbeeld een directe bijdrage geleverd aan de jaarlijkse MINT-cursus 'Voeding in het verpleeghuis: van aandacht tot aanpak'.

Begin 2007 werd in een trekkersrol, in Maastricht, samen met de onafhankelijke nascholingsorganisator IPC-Neurobrain, de eerste maal een meerdaagse cursus Ouderengeneeskunde georganiseerd. Deze cursus richt zich op verpleeghuisartsen, klinisch geriaters, sociaal geriaters en neurologen. ${ }^{6}$

In 2008 is deze interessante en voortaan jaarlijkse, 3-daagse cursus voor de tweede maal georganiseerd.

Vermelding verdient hier tenslotte nog de redactionele medewerking vanuit UM-verpleeghuisgeneeskunde aan de tweede druk van het dit jaar eveneens verschenen Geriatrie Formularium, dat, vanwege zijn handzame karakter, in de praktijk door vele artsen en artsen in opleiding gebruikt wordt. 57

\section{Verpleeghuisgeneeskundig onderzoek in en vanuit de Faculty of Health, Medicine and Life Sciences (FHML); UM}

De onderzoekstraditie van het pas in 1990 erkende vakgebied van de verpleeghuisgeneeskunde is in ons land nog maar beperkt. Research op dit gebied wordt verricht aan de universiteiten van Amsterdam (VUMC), Nijmegen en Leiden en sinds enige tijd dus ook Maastricht.

De benadering van onderzoek in dit ten principale brede generalistisch specialisme mag en kan in aanvang dan ook opportunistisch zijn.

Ter verdere onderbouwing van het vakgebied bestaat binnen de verpleeghuisgeneeskunde een grote behoefte aan onderzoek dat nader inzicht zal verschaffen in bijvoorbeeld de specifieke kenmerken van verpleeghuispatiënten, in de specifieke klinische en zorgproblemen die zij hebben, in het beloop van hun patiëntencarrière, in de daadwerkelijke zorg die ze krijgen en in de effecten daarvan. Een en ander zal gestalte moeten krijgen via kwalitatief verantwoord epidemiologisch onderzoek, via longitudinaal observationeel en experimenteel patiëntgebonden beloops-en interventieonderzoek en door de ontwikkeling plus validering van voor de verpleeghuispopulatie geschikte meetinstrumenten en uitkomstmaten. 
De verpleeghuisgeneeskundige inbreng in de ketenzorg voor specifieke doelgroepen (w.o. patiënten met een CVA, patiënten met een behoefte aan revaliderende herstelzorg, patiënten met dementie en patiënten met behoefte aan palliatieve zorg) is eveneens een interessant onderwerp van onderzoek.

In dit kader past ook (samenwerkings)onderzoek in de medische as huisarts - verpleeghuisarts - medisch specialist; en t.a.v. de laatste in het bijzonder de klinisch geriater / internist ouderen en de ouderenpsychiater.

Inmiddels worden aan de Universiteit Maastricht, in samenwerking met andere universitaire partners, het azM en het praktijkveld onderzoeksactiviteiten ontwikkeld op de volgende aandachtsgebieden:

1. Essentiële zorgproblemen van verpleeghuispatiënten, w.o. bijvoorbeeld ondervoeding en vallen;

2. Verpleeghuisgeneeskunde en verpleeghuiszorg voor ter herstel en revalidatie opgenomen verpleeghuispatiënten (post CVA, post orthopedische ingreep e.d.);

3. Verpleeghuisgeneeskunde en verpleeghuiszorg voor patiënten met dementie;

4. Verpleeghuisgeneeskunde en palliatieve zorg;

5. Verpleeghuisgeneeskunde/verpleeghuiszorg en (zorg)ethiek;

6. Ontwikkelingen op het gebied van de medische, respectievelijk chronische zorg voor ouderen.

1. Essentiële zorgproblemen van verpleeghuispatiënten, w.o. bijvoorbeeld ondervoeding en vallen

Vanuit UM-verpleeghuisgeneeskunde wordt direct geparticipeerd in de Landelijke Prevalentiemeting Zorgproblemen, die onder leiding van Ruud Halfens uitgevoerd wordt vanuit het FHML-department Health Care and Nursing Sciences.

De Landelijke Prevalentiemeting Zorgproblemen (LPZ) is een jaarlijks terugkerende prevalentiemeting van zorgproblemen binnen de Nederlandse gezondheidszorg, waaronder decubitus, incontinentie, ondervoeding, vallen \& fixatie en smetten..$^{8}$

Met de meting krijgen deelnemende instellingen uit alle relevante 
sectoren van de gezondheidszorg op patiënt-, afdelings- en organisatieniveau inzicht in de prevalentie en het beleid m.b.t. de onderzochte zorgproblemen. Inzicht in de omvang van een zorgprobleem kan instellingen en beleidsmakers stimuleren maatregelen te nemen, zoals het preventief screenen op het zorgprobleem en het voorkomen of bestrijden ervan. Doordat de meting bij een groot aantal instellingen plaatsvindt, kunnen de deelnemende instellingen zich bovendien vergelijken met soortgelijke instellingen en zijn de gegevens te gebruiken als benchmarkinstrument.

De meting sluit bovendien nauw aan bij de door de inspectie voor de gezondheidszorg (IGZ) gewenste prestatie-indicatoren.

UM-verpleeghuisgeneeskunde heeft, vanuit bijzondere belangstelling, vooral bijgedragen aan de ontwikkeling van de LPZ-meting voor de zorgproblemen ondervoeding en vallen\&fixatie.

Komend jaar zal Judith Meijers naar verwachting promoveren op gepubliceerde LPZ-activiteiten m.b.t. het vóórkomen van ondervoeding in de Nederlandse gezondheidszorg, waaronder ook de verpleeghuissector, alsmede op artikelen die verschenen zijn naar aanleiding van activiteiten vanuit de 'Working Group on Nutrition' van de European Pressure Ulcer Advisory Panel (EPUAP), die gekoppeld zijn aan het thema decubitus en voeding.

Inmiddels is een nieuw project gestart waarin Noémi van Nie de prevalentie van en het beleid t.a.v. ondervoeding in de gezondheidszorg in verschillend EU-landen zal onderzoeken.

Ook worden in samenwerking met prof. Annemie Schols, voorbereidingen getroffen voor een onderzoek naar het bestaan van een eventuele primaire Alzheimercachexie.

Met betrekking tot het zorgprobleem vallen promoveerde Jacques Neyens in 2007 op een proefschrift over een in een randomized controlled trial (RCT) uitgeteste multifactoriële interventie ter preventie van valincidenten bij dementerende verpleeghuisbewoners. Hij is sindsdien betrokken bij nieuwe activiteiten op dit gebied.

Nieuw is het onderzoek naar de prevalentie en diagnostiek van hartfalen in het verpleeghuis, dat onder leiding van prof. Jan Hamers en mijzelf door verpleeghuisarts Mariëlle van der Velden verricht wordt. In dit 
onderzoek wordt samengewerkt tussen UM-verpleeghuisgeneeskunde, UM-verplegingswetenschap, de afdeling Cardiologie van het Maastrichts Universitair Medisch Centrum-plus (MUMC+) en de afdeling Cardiologie van het Universitair Medisch Centrum Groningen (UMCG).

Tenslotte moet, wat het thema zorgproblemen betreft, nog de directe betrokkenheid genoemd worden bij een drietal promotie-onderzoeken betreffende de mondzorg in verpleeghuizen vanuit BENECOMO, het Belgisch Nederlands Consortium Mondzorg, een samenwerking tussen de afdeling Geriatrische Tandheelkunde o.I.v. prof. Cees de Baat van het Universitair Medisch Centrum St Radboud te Nijmegen, de afdeling maatschappelijke tandheelkunde van de Vakgroep Tandheelkunde, van de Universiteit van Gent, o.I.v. prof. Jackie Vanobbergen en UM-verpleeghuisgeneeskunde.

2. Verpleeghuisgeneeskunde en verpleeghuiszorg voor ter herstel en revalidatie opgenomen verpleeghuispatiënten (post CVA, post orthopedische ingreep e.d.)

De herstel- en revalidatiezorg in en vanuit verpleeghuizen maakt, zoals enkele malen gememoreerd, een sterke ontwikkeling door.

In Maastricht zal dit, zoals ook al genoemd, op niet al te lange termijn leiden tot de bouw van een nieuwe specifieke herstelkliniek, als initiatief van Vivre, Stichting Clara Fey en het MUMC+, waaronder de RVE Transmurale Zorg.

Het zal duidelijk zijn dat dit ook kansen biedt voor nader wetenschappelijk onderzoek op dit gebied.

Op dit moment is UM-verpleeghuisgeneeskunde reeds betrokken bij een tweetal onderzoeken.

Zo is er het onderzoek naar Mental Practice in post stroke rehabilitation dat uitgevoerd wordt door Susy Braun van de Hogeschool Zuyd en het onderzoek van Ron Heijnen, verpleeghuisarts van Vivre, dat gericht is op de (kosten)effectiviteit van het invoeren van een vervroegde verwijzing naar én multidisciplinair assessment in het verpleeghuis van CVA patiënten. 
3. Verpleeghuisgeneeskunde en verpleeghuiszorg voor patiënten met dementie

In nauwe samenwerking met prof.Frans Verheyvan devakgroep Psychiatrie en Neuropsychologie van het MUCM+ én van het Alzheimer Centrum Limburg is het onderzoek naar de zorg voor verpleeghuisbewoners met bovengemiddeld probleemgedrag en een behoefte aan dubbelzorg (d.i. verpleeghuiszorg en psychiatrische zorg) voorbereid. Het onderzoek wordt uitgevoerd door verpleeghuisarts/sociaal geriater Janine Collet.

Samen met Wageningen Universiteit wordt gewerkt aan een onderzoek naar de effecten van zorgboerderijen op het functioneren en de kwaliteit van leven van dementerenden.

Verder wordt, opnieuw in samenwerking met prof. Frans Verhey gewerkt aan de voorbereiding van een onderzoek m.b.t. een interventie, die verzorgend personeel van verpleeghuizen beter moet toerusten om adequaat om te gaan met probleemgedrag bij dementerende verpleeghuispatiënten. Samenwerking zal hierbij plaatsvinden met de Stichting Proteion in Horn e.o.

\section{Verpleeghuisgeneeskunde en palliatieve zorg}

Op het gebied van de palliatieve zorg verdient de betrokkenheid van UM-verpleeghuisgeneeskunde bij het prachtige onderzoeksproject van verpleeghuisarts Daisy Janssen vermelding; een project dat zij onder supervisie van prof. Miel Wouters, Martijn Spruijt en mijzelf uitvoert. Het project is getiteld Self-perceived symptoms and care needs of patients with severe to very severe chronic obstructive pulmonary disease and their consequences for the closest relatives and the treating physician.

Hierin worden de dagelijkse problematiek en noden van patiënten met ernstige tot zeer ernstige COPD in kaart gebracht. Om de ernst van de problemen en noden van deze patiënten beter te kunnen inkaderen worden, ter vergelijking, ook de dagelijkse problemen en noden bij twee andere patiëntengroepen met chronisch orgaanfalen (ernstig chronisch hartfalen en ernstig chronisch nierfalen) in kaart gebracht. Verder wordt onderzocht of en hoe patiënten met ernstige of zeer ernstige COPD over de laatste fase van hun leven communiceren met hun naasten en hun behandelend medisch specialist en hoe de patiënten en hun familie tegenover het opstarten van levensverlengende behandelingen staan. 
De voorkeuren van deze patiënten ten aanzien van levensverlengende behandelingen worden voorts vergeleken met die van patiënten met ernstig chronisch hart- of nierfalen.

Het design is een longitudinale studie waarin de patiënten 1 jaar gevolgd worden om het verloop van de problematiek te bestuderen. Indien patiënten met ernstige tot zeer ernstige COPD overlijden gedurende de follow-up periode, wordt achteraf nagegaan of de persoonlijke voorkeuren van (levensverlengende) behandelingen gedurende de laatste fase van het leven praktisch mogelijk waren en zijn gerespecteerd door de naaste familie en de verantwoordelijke arts.

\section{Verpleeghuisgeneeskunde/verpleeghuiszorg en (zorg)ethiek;}

Samenhangend met het voorgaande thema past ook de interactie tussen verpleeghuisgeneeskunde en zorgethiek. Het gaat dan niet alleen om de ethiek gekoppeld aan belangrijke cure - care beslissingen, maar ook om de ethiek van alledag, in de wisselwerking tussen bijvoorbeeld verpleeghuispatiënt en verpleeghuisorganisatie of verpleeghuispatiënt en verpleeghuispersoneel.

In samenwerking met de afdeling Zorgethiek is UM-verpleeghuisgeneeskunde direct betrokken bij twee projecten Moreel Beraad in zorginstellingen, die naar verwachting ook zullen leiden tot twee promoties.

6. Ontwikkelingen op het gebied van de medische respectievelijk chronische zorg voor ouderen.

In de nabije toekomst zal het aantal patiënten dat transmurale verpleeghuiszorg ontvangt fors groeien. De transmurale verpleeghuisgeneeskunde vereist derhalve, met het oog op de maatschappelijke relevantie, nadere wetenschappelijke onderbouwing.

In Maastricht zal transmuraal onderzoek geïnitieerd worden, waarbij naast verpleeghuizen ook andere zorgaanbieders betrokken zijn. Het is daarbij belangrijk om ook aandacht te besteden aan de relatie tussen verpleeghuiszorgonderzoek en verpleeghuisgeneeskundig onderzoek. Integratie van verpleeghuisgeneeskundig onderzoek en (verpleeghuis) zorgonderzoek kan bereikt worden door in patiëntgebonden onderzoek na te gaan wat de structuur van de (verpleeghuis)zorg voor invloed heeft op het zorgproces in het algemeen en de medische zorg in het bijzonder. 
Aspecten zoals leefklimaat, de beschikbaarheid en deskundigheid van verpleeghuismedewerkers en de context waarin de verpleeghuiszorg geboden wordt (in het verpleeghuis of daarbuiten) hebben immers ook een duidelijke invloed op de uitkomst van het zorgproces en op het proces van de transmurale samenwerking. De beschreven actuele ontwikkelingen op het gebied van wonen, zorg en welzijn voor kwetsbare ouderen en chronisch zieken in ons land, zullen hierin eveneens meegenomen worden.

De recente oprichting van het Academisch Centrum ZorgInnovatie Ouderen (ACZIO) en het reeds genoemde Nationaal Programma Ouderenzorg (NPO) van ZONMW zullen hopelijk mogelijkheden opleveren om ook in en vanuit Maastricht relevante onderzoeken uit te voeren naar deze aspecten en naar de reeds genoemde pluriforme rol van de verpleeghuisarts in het totale zorgnetwerk voor kwetsbare ouderen $\cdot 48,49$

Het is duidelijk dat het verpleeghuisgeneeskundig onderzoek nu nog vrij pluriform is, hetgeen past bij de veelzijdigheid van het vakgebied en de fase van ontwikkeling ervan in de UM.

In de komende jaren is het belangrijk deze projecten, met de vooralsnog bescheiden formatie, tot een goed einde te brengen. Op termijn zal er in het onderzoek uiteraard sterker gefocust moeten worden, maar het leggen van de toekomstige focus wordt mede bepaald door de spin off van de lopende projecten en door het al of niet succesvol verlopen van de samenwerking met anderen.

\section{Samenwerking met relevante partners binnen en buiten de UM en met de Limburgse verpleeghuizen}

Het in Maastricht startende en in de tijd nog jonge verpleeghuisgeneeskundig onderzoek werkt sterk vanuit een netwerkgedachte en kan derhalve profiteren van de geschikte omgeving waarin ze tot ontwikkeling kan komen.

De leerstoel Verpleeghuisgeneeskunde is verbonden aan de Vakgroep Huisartsgeneeskunde, hetgeen betekent dat het verpleeghuisgeneeskundig onderzoek in Maastricht haar voordeel kan doen met de enorme knowhow die daar inmiddels t.a.v. het huisartsgeneeskundig onderzoek aanwezig is.

Het onderzoek is verder ondergebracht bij het onderzoeksinstituut 
Caphri (in het onderzoeksprogramma "Innovations in health care for the elderly" (o.l.v. prof. Ruud Kempen \& prof. Jan Hamers).

Caphri maakt onderdeel uit van de onderzoekschool Care. Daarmee kan en zal ook samenwerking plaatsvinden met diverse participanten binnen Care.

De profilering van de verpleeghuisgeneeskunde in en vanuit de UM krijgt verder gestalte door een goede samenwerking met andere relevante partners binnen en buiten de UM.

Binnen de UM betreft dit in het bijzonder andere UM-leerstoelhouders, die sterk geïnteresseerd zijn in onderzoek op het gebied van ouderen, ouderenzorg en ouderengeneeskunde. Het gaat bijvoorbeeld om de leerstoelen: sociale gerontologie, ouderenpsychiatrie/ neuropsychiatrie, verpleging \& verzorging van ouderen, zorgethiek en huisarts-geneeskunde. Ook de samenwerking met de internisten ouderengeneeskunde in het azM is in ontwikkeling evenals met vakgroepen zoals Neurologie, Cardiologie en Pulmonologie.

Vanuit UM-Verpleeghuisgeneeskunde wordt, zoals eerder genoemd, geparticipeerd in het ACZIO (Academisch Centrum ZorgInnovatie Ouderen) waaraan naast UM- en azM-afdelingen ook zorgaanbieders, welzijnsorganisaties, provincie, gemeenten en andere relevante partijen deelnemen.

Mede via dit centrum zal in de toekomst gepoogd worden om substantiële subsidies voor wetenschappelijke projecten binnen te halen als ook voor zorginnovaties in het veld van de chronische zorg in Limburg.

Ten aanzien van de zorgaanbieders wordt door UM-Verpleeghuisgeneeskunde uiteraard t.b.v. onderwijs en onderzoek samengewerkt met de Limburgse verpleeghuisorganisaties, waarvan er een aantal, te weten Vivre in Maastricht e.o., Sevagram in Heerlen e.o., MeanderGroep in Kerkrade e.o. en Proteion in Horn e.o. al langer een duurzame samenwerkingsrelatie met de UM onderhouden.

De banden met andere Limburgse verpleeghuisorganisaties w.o. Orbis Medisch en Zorgconcern in Geleen en Sittard e.o, Cicero Zorggroep in Brunssum e.o., Land van Horne in Weert e.o. en de Zorggroep Noord en Midden-Limburg zijn inmiddels aangehaald en ze zullen de komende jaren verder versterkt worden t.b.v. onderwijs en wetenschappelijk 
onderzoek, om zo als het ware in heel Limburg academische werkplaatsen voor onderwijs en onderzoek te genereren.

Samenwerking en afstemming met universitaire groepen en netwerken van elders is, waar aangewezen en relevant, ook een reële optie, w.o. met name de Academische Werkplaats Chronische Zorg van het departement Tranzo van de Universiteit van Tilburg en het Universitair VerpleeghuisNetwerk van de Radboud Universiteit Nijmegen, omdat de uitvoering van onderzoeksactiviteiten nu al deels plaatsvindt in de adhaerentiegebieden van deze beide netwerken en er vanuit Limburg eveneens wederzijds geparticipeerd wordt aan activiteiten van deze netwerken.

Verder kan concreet gedacht worden aan NIVEL, RIVM, SCP en VILANS, waar nu reeds contacten mee bestaan.

Uiteindelijk geldt dit ook voor potentiële internationale partners op het gebied van de ouderenzorg en ouderengeneeskunde. 


\section{Epiloog}

Mijnheer de Rector, gewaardeerde toehoorders, de problematiek van grijs is veelkleurig zoals hoogleraar Johan Polder het begin dit jaar noemde in zijn oratie aan de Universiteit van Tilburg.

Die problematiek vraagt om een vernieuwende en integrale aanpak waarin de verpleeghuisgeneeskunde als complementaire partner samen met andere medische en niet medische disciplines een herkenbare rol kan en zal spelen en uiteindelijk, als ze de haar geboden uitdagingen proactief aangaat, breed gekend zal zijn. De on bekendheid die, op de kaft van dit boekje, ook speekt uit de Chinese vertaling van het Engelse 'Nursing home medicine, recognized?' zal dan verdwenen zijn.

In en vanuit de Universiteit Maastricht zullen we daar in ieder geval als echte netwerkers voor gaan!

Ik hoop U daarvan te hebben overtuigd. 


\section{Dankwoord}

Mijnheer de rector, Dames en Heren,

Aan het einde gekomen van mijn betoog, rust op mij de aangename taak woorden van dank uit te spreken tot degenen die hebben bijgedragen aan mijn benoeming. Dat wil ik niet plichtmatig doen, en ik verzeker $u$ dat ze recht uit mijn hart komen.

Het College van Bestuur van de Universiteit Maastricht en het Bestuur van het MUMC+ (w.o. de FHML) dank ik voor het in mij gestelde vertrouwen.

Ik wil mijn dank in het bijzonder betuigen aan de Raad van Bestuur en de Raad van Toezicht van Vivre en ook aan de Stichting Elisabeth Strouven op wier initiatief deze bijzondere leerstoel tot stand is gekomen. Daarbij passen in het bijzonder veel woorden van dank voor Jan Meijers en Gauke Kootstra en verder voor Dik Mol.

Voorts ook voor Wim te Nijenhuis en Jan Wijnen, de beide voorgangers van de huidige Raad van Bestuur.

Ik dank Vivre in het bijzonder ook voor de mogelijkheden die men mij elke dag biedt om mijn wetenschappelijke belangstelling daadwerkelijk in de praktijk te brengen.

De continue steun en belangstelling die ik van Raad van Bestuur, managementteam, locatiemanagers, alle verpleeghuisartsen, psychologen en paramedici, vertegenwoordigers van de verpleging \& verzorging en van alle ondersteunende diensten ondervindt, waardeer ik zeer.

Binnen de UM dank ik prof. Job Metsemakers en via hem alle collega's binnen de Vakgroep Huisartsgeneeskunde voor de gastvrijheid waarmee men het vakgebied een plaats heeft gegund. Job, jij hebt er samen met je voorganger Harry Crebolder eveneens voor gezorgd dat de UM heeft gekozen voor de instelling van deze leerstoel. In ons regelmatig werkoverleg laat je je belangstelling voor alle activiteiten, die ik ontplooi, steeds oprecht blijken.

Paul Zwietering, oud studiegenoot en ook werkzaam bij HAG, draagt er nadrukkelijk toe bij dat de verpleeghuisgeneeskunde een plek krijgt in 
het basiscurriculum en dat Rachele Arends, mijn collega verpleeghuisarts uit Vivre haar onderwijstaken niet alleen op enthousiaste wijze, maar ook gewoon goed, kan vervullen.

Ook dank ik het Instituut Caphri in de personen van prof. Guy Widdershoven en prof. Onno van Schayck.

Verder binnen Zorgwetenschappen natuurlijk prof. Jan Hamers en prof. Ruud Kempen voor de fijne en vriendschappelijke samenwerking.

Datzelfde geldt in het bijzonder ook voor Ruud Halfens en de collega's bij de LPZ.

Uiteraard dank ik ook Prof. Frans Verhey voor de plezierige samenwerking en contacten en voor zijn continue belangstelling voor hetgeen zich in de verpleeghuiswereld afspeelt.

Andere belangrijke MUMC+ personen, aan wie ik dank verschuldigd ben, zijn prof. Miel Wouters en prof. Martien Limburg.

Met prof. Annemie Schols, mijn slimme zus, zet ik nu ook de eerste schreden m.b.t. een onderzoeksproject op het gebied van voeding. Dat mocht immers niet overgeslagen worden.

Verder dank ik de afdeling Transmurale Zorg in de persoon van Hans Fiolet voor de prettige samenwerkingscontacten en voorts Guy Schulpen inzake de samenwerking met de huisartsen in Maastricht/Heuvelland.

Uiteraard dank ik natuurlijk oprecht alle promovendi, waarvan de meesten eerder genoemd zijn; én ook de bij hen betrokken begeleiders. In de angst iemand te vergeten, noem ik hier verder geen namen. Het contact met jullie allemaal is steeds opnieuw inspirerend.

Dat geldt ook voor de studenten waarbij ik betrokken ben.

25 Jaar geleden, in 1983, studeerde ik af aan deze universiteit. In mijn functie als verpleeghuisarts heb ik in alle jaren daarna veel kwetsbare ouderen en hulpbehoevende patiënten mogen behandelen en begeleiden. Zij zijn voor mij altijd de drijfveer geweest voor mijn wetenschappelijke activiteiten. Ik dank hen dan ook oprecht voor hun levenswijsheid, waarvan ik veel heb mogen leren.

Natuurlijk ben ik ook veel dank verschuldigd aan alle reeds genoemde verpleeghuisorganisaties hier in Limburg. Hun belangstelling voor participatie aan onderwijs en onderzoek is zeer bemoedigend. 
Ik zie uit naar de verdere uitbouw van deze samenwerking, ook met andere partners, in ACZIO-verband.

Datzelfde geldt ook voor de HSZuyd, met wie ik vanuit de UM en Vivre ook goede contacten onderhoud.

De Nederlandse Vereniging van Verpleeghuisartsen (NVVA) dank ik voor de warme en ondersteunende belangstelling, die ze steeds heeft gehad voor mijn activiteiten.

Datzelfde geldt voor de Afdeling Verpleeghuisgeneeskunde van het Universitair Medisch Centrum St Radboud te Nijmegen, waar ik een aantal jaren 1 dag per week heb mogen werken. Speciale dank gaat daarbij uit naar Raymond Koopmans en Jan Lavrijsen.

Voorts dank ik de collega hoogleraren Verpleeghuisgeneeskunde in Amsterdam en Leiden.

In de afgelopen jaren heb ik, in mijn andere functie van hoogleraar Chronische Zorg in Tilburg, vele positieve en warme ervaringen opgedaan in de samenwerking met de collega's binnen het departement Tranzo van de Universiteit van Tilburg.

Speciale woorden van dank gaan daarbij uit naar Katrien Luijkx, met wie ik het meeste heb samengewerkt. Ik dank ook prof. Henk Garretsen en prof. Aad de Roo, de enthousiaste leiders van het Tranzoteam en natuurlijk de participanten van de Academische Werkplaats Chronische Zorg.

Verder dank ik nog Frank Staal, mijn vroegere directe collega in de RvB van de Riethorst in Geertruidenberg e.o.( nu de Riethorst Stromenland geheten) voor de al jaren bestaande vriendschap evenals Peter Span, directeur-bestuurder van WSG, de Woningstichting Geertruidenberg e.o., die op het gebied van innovatieve woonvormen voor ouderen, zulke mooie projecten realiseert.

Natuurlijk zijn er, zoals genoemd nog vele andere externe partners, collega's en bevriende relaties, met wie ik dankbare contacten onderhoud, maar ook hier streef ik, in de vrees er een te vergeten, geen volledige opsomming na.

Vermelding verdient nog wel BENECOMO, het reeds genoemde Belgisch Nederlands Consortium Mondzorg dat ik in de personen van prof. Cees de Baat uit Nijmegen en prof. Jackie Vanobbergen uit Gent dank voor de inspirerende contacten. 
En zo hebben nog veel meer mensen en instanties mij in mijn loopbaan geïnspireerd, gesteund en laten zien hoe dingen wel en niet gedaan moeten worden. Teveel dus om op te noemen; maar weet dat ik ook hen dankbaar ben!

Mijn ouders, broer en zus dank ik natuurlijk ook.

Maar.... de meeste dank gaat tenslotte uit naar Maria; en ook Laurens, Rutger, Floris, Myrthe, en Emma.

Jullie zijn mij echt het dierbaarst.

Jullie geloven in me en jullie lachen me soms ook uit; én soms gaat het er thuis lekker hectisch aan toe. Ik zou daar echter niet zonder kunnen, want dan is het lang zo leuk niet meer.

Daarom draag ik deze rede ook aan jullie op.

Dames en Heren, graag wil ik $u$ allen hier aanwezig danken voor uw komst en belangstelling.

Ik heb gezegd! 


\section{LITERATUUR}

1. Beek C van. Medimetaforen; beeldspraak in de geneeskunde. Van der Wees Uitgeverij, Utrecht 2001.

2. Froeling PGAM. Hoe nu verder? Oratie. Katholieke Universiteit Nijmegen, 1998.

3. Koopmans RTCM. Professionalisering van de verpleeghuisgeneeskunde; naar een verbinding van praktijk en wetenschap. Oratie. UMC St Radboud, Nijmegen, 2005.

4. Schols JMGA. In en vanuit het verpleeghuis. Samenwerking verpleeghuisarts - huisarts. (Dissertatie). Raamsdonksveer: Vèrse Hoeven uitgeverij, 2000.

5. Heyne G, Vermaas J, Wüstefeld C, Joldersma C, Geurts J. Een onderzoek naar de chronische ouderenzorg in Nederland (DIAGNOST-project). Tilburg: IVA, 1995.

6. SCP-rapportage ouderen 2004. Zorg en wonen voor kwetsbare ouderen. (Red. MMY de Klerk). Den Haag: Sociaal Cultureel Planbureau, mei 2004.

7. Nota: Ouderen in Tel. Beeld en beleid rond ouderen 1990-1994. Tweede Kamer, vergaderjaar 1990-1991, 21814, nrs 1-2.

8. www.brancherapporten.minvws.nl (trefw. verpleeghuizen).

9. Schols JMGA, Crebolder HFJM, Weel C van. Nursing home and nursing home physician: the Dutch experience. JAMDA 2004; 5(3): 207-12.

10. Schols JMGA, Frijters DHM, Koopmans RTCM, Diederiks JPM, Sturmans F, Crebolder HFJM. Verpleeghuisdagbehandeling: een groeiende functie voor een tamelijk vast omschreven doelgroep. Tijdschr Gerontol Geriatr 1998;29:244-9.

11. Schols JMGA, Wierik MJM te. Verpleeghuiszorg buiten de muren: dagbehandeling, consultatie en substitutieprojecten. Ned Tijdschr Geneeskd 1993;137(52):2686-9.

12. Robben PBM. Oudere chronische patiënten en hun voorzieningen in de eerste helft van de twintigste eeuw. Tijdschr Gerontol Geriatr 1998;29:168-76.

13. Oostvogel FJG. De historische ontwikkeling van het verpleeghuis. In: Trommel J, Ribbe MW, Stoop JA (red), Capita Selecta van de Verpleeghuisgeneeskunde. Utrecht/Antwerpen, 1989:3-19. 
14. Rapport: Rust- en verpleegtehuizen KNMG. Medisch Contact 1961;34:545-8.

15. NVVA. Functieomschrijving en takenpakket van de verpleeghuisarts. Utrecht. NVVA/Berenschot, 1992.

16. Ribbe MW, Ooms ME. Wal G van der,Eijk JThM. Wetenschappelijk onderzoek in de verpleeghuisgeneeskunde: een voorwaarde voor professionalisering. Ned Tijdschr Geneeskd 1995;139(36):1851-5.

17. NVVA/NVSG. Nota Takenpakket Verpleeghuisarts/Sociaal Geriater. Utrecht, 2003. (zie www.verpleeghuisartsen.nl)

18. Cools HJM. Het ultieme vangnet. Kleinschalige zorghuizen maken verpleeghuis niet overbodig. Medisch Contact 2007;62(43):1774-7.

19. Bransen E, Hulsbosch L, Nicholas S, Wolf J. Kwetsbare mensen over samenhang in de zorg.Utrecht: Trimbos-instituut, 2003.

20. Peperzeel HA van, Engel GL. (red.). Geen tijd om ziek te zijn. Beeld van gezondheidszorg. Den Haag: SMO, 1993.

21. Schols JMGA. De toekomst van de chronische zorg, ons een zorg? Van oude structuren, de dingen, die voorbijgaan... Oratie Universiteit van Tilburg, 2004.

22. Heuvel-Olaroiu M van den. Genoeg handen, maar niet de juiste. Ouderenzorg ontbeert voldoende professionaliteit. Medisch Contact 2007;62(38):1543-5.

23. Pay-Uun H. Ligduur in ziekenhuis gehalveerd. Bericht in Volkskrant 14/15 augustus 2004, n.a.v. rapport inzake jaarlijkse Landelijke Medische Registratie (LMR) van Prismant.

24. Actuele kerncijfers over de ziekenhuiszorg 2003. Utrecht: Prismant, LMR, 2004.

25. Boeije HR, Dungen A van den, Pool A, Grypdonck M, Lieshout P van. Een verzorgde toekomst; toekomstscenario's voor verpleging en verzorging. Utrecht: NIZW/Universiteit van Utrecht, 1997.

26. STG. Stichting Toekomstscenario's Gezondheidszorg. Welzijn en waardigheid voor langdurige zorggebruikers. Op weg naar 2020. Maarssen: Elsevier gezondheidszorg, 2003 (1e druk, 2e oplage).

27. www.iwz.nl

28 Www.vilans.nl

29. Raak A van, Mur-Veenman I, Hardy B, Steenbergen M, Paulus A. Integrated care in Europe. Description and comparison of integrated care in six EU countries. Maarssen: Elsevier gezondheidszorg, 2003. 
30 Raak A van, Mur-Veenman I, Paulus A. Understanding the feasibility of integrated care: a rival viewpoint on the influence of actions and the institutional context. The International Journal of Health Planning and Management 1999; 14:235-48.

31. Keizer B. Weerloos. Medisch Contact 2006;61(46):1843.

32. Westendorp RGJ. Medische zorg voor ouderen onder de maat. Zucht naar concurrentie frustreert ontwikkeling ketenzorg. Medisch Contact 2006;61(44):1748-51.

33. Staat van de gezondheidszorg 2003. Ketenzorg bij chronisch zieken. http://www.igz.nl/bestanden/SGZ_2003=def=A4_per_ pagina.pdf

34. Bergman H, Béland F, Karunananthan S, Hummels S, Hogan D, Wolfson C. Dévelopment d'un cadre de travail pour comprendre et étudier la fragilité. Gérontologie et Societé $2004 ; 109$ :15-29.

35. Gobbens RJJ, Luijkx KG, Wijnene-Sponselee MT, Schols JMGA. Towards an integral conceptual model of frailty. Submitted for publication.

36. Ouderdom komt met gebreken. Geneeskunde en zorg bij ouderen met multimorbiditeit. GR-rapport nr. 2008/01. Gezondheidsraad, 2008, Den Haag. Zie www.gr.nl

37. Dam van Isselt EF van, Schols JMGA. De verpleeghuisarts in consult: een te weinig benutte toegevoegde waarde. Tijdschr Gerontol Geriatr 2007; 38(5):255-261.

38. Dam van Isselt EF van, Schols JMGA, Hageman MLP. De verpleeghuisarts in consult: Winst voor huisarts en patiënt. Huisarts en Wetenschap, 50(7), 325-328.

39. Wolfs C. An integrated approach to dementia; a clinical and economic evaluation. Proefschrift UM, 2007.

40 Koenen C, Borst V, Temmink AH, Jonckheere R, Kroot LAJ, Maas $M$, Schols JMGA. Samenwerking verpleeghuis, ziekenhuis en GGZ; De aanvullende waarde van ambulante, multidisciplinaire ziekte- en zorgdiagnostiek in een geriatrisch centrum. Tijdschr Verpleeghuisgeneeskd 2005;3-(5):6-11.

41. Schols JMGA. Verpleeghuiszorg vooruit! Elimineren veiligheidsrisico's verbetert zorg aan ouderen. Medisch Contact 2007; 62(23):984-6.

42. Spijkers KFJ, Francke AL, Schols JMGA. Rapport: Indicatoren voor medische zorg in verpleeghuissettings, NIVEL, Utrecht 2007.

43. Spreeuwenberg C. Www.mychronicdisease.org; naar de patiënt activerende en ondersteunende chronische zorg. Afscheidsrede 
UM 2008.

44. Cools HJM, Valkhof AJM, Went PBM. Zorgregie van samengestelde zorg. In Cursusboek Vorderingen Verpleeghuisgeneeskunde (ISBN 90-6767-459-1), BoerhaaveCommissie, Leiden, 28 september 2000.

45. Graas T de, Slaets JPJ, Schildkamp HThA, Braak GJ ter, Schuylenburg $L$ van, Albersnagel-Thijssen EPL. Meer dan gezondheid. Ouderenzorg vereist een integrale visie en opleiding. Medisch Contact 2008; 63(13):554-7.

46. http://nhg.artsennet.nl/content/resources//AMGATE_ 6059_104_TICH_R1575721004909119//

47. Polder J, Wong A, Schols JMGA. Toename levensverwachting remt uitgaven ouderenzorg. ESB 2008; 93(4539):422-5.

48 Nationaal Programma Ouderenzorg-ZONMW; wwW.zonmw.nl

49. Baur VE, Kemepen GIJM, Schols JMGA, Verhey FRJ, Hamers JPH, Widdershoven GAM. Academisch Centrum ZorgInnovatie Ouderen (ACZIO); eindrapportage mei 2008. UM - Caphri, Maastricht, 2008.

50. Konings J, Schols JMGA. Expertisecentra; van verpleeghuis naar ouderenzorg-expertisecentrum en tweedelijns-zorgcentrum. Tijdschr Verpleeghuisgeneeskd 2007; 32(1):3-5.

51. http://www.iagg.com.br/PdfNoticias//AGG200831110919.pdf

52. http://www.unimaas.nl/default.asp?template=werkveld.htm\&i

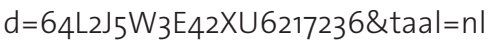

53. Flamaing J, Hoefnagels WHL, Olde Rikkert MGM, Petrovic $M$, Schols JMGA. Probleemgeoriënteerd denken in de geriatrie. Een praktijkboek voor de opleiding en de kliniek. De Tijdstroom, Utrecht, 2008.

54. Zijlstra E.(6ejaars co-assistent geneeskunde UMC St Radboud). Allin voor de oudere; een essay. In: Flamaing J, Hoefnagels WHL, Olde Rikkert MGM, Petrovic M, Schols JMGA. Probleemgeoriënteerd denken in de geriatrie. Een praktijkboek voor de opleiding en de kliniek. De Tijdstroom, Utrecht, 2008.

55. Vernooij L. (6e jaars co-assistent geneeskunde UMC St Radboud). Keukenkastjes; een essay. In: Flamaing J, Hoefnagels WHL, Olde Rikkert MGM, Petrovic M, Schols JMGA. Probleemgeoriënteerd denken in de geriatrie. Een praktijkboek voor de opleiding en de kliniek. De Tijdstroom, Utrecht, 2008.

56. http://www.ipcneurobrain.nl 
57. Jansen PAF, Laan JR van der, Schols JMGA. Het Geriatrie Formularium; een praktische leidraad; ze editie. Bohn Stafleu van Loghum, Houten, 2007.

58. http://www.lpz-um.nl 

